\title{
Economics
}

HEI Working Paper No: 04/2008

\section{A new way to link development to institutions, policies and geography}

\author{
Sudip Ranjan Basu
}

United Nations

Conference on Trade and Development, Geneva

\begin{abstract}
The paper aims to examine the role of institutions relative to economic policy and geography in explaining the differential level of development across countries over time. To that end, it attempts to construct a Development Quality Index (DQI) and an Institutional Quality Index (IQI) by using multivariate statistical method of principal components. It shows that (i) higher level of IQI along with economic policy and geography factors lead to a positive improvement in the level of DQI; and (ii) results remain robust for IQI and relatively robust for economic policy and geography even when it is compared across cross-section and panel data estimation for a set of 102 countries over 1980 to 2004. The results strongly indicate that institutions matter in the context of specific economic policy mixes and geography related factors illustrated by disease burden, etc. It demonstrates that relative influence of institutions varies across stages of development.
\end{abstract}

(C) The Authors.

All rights reserved. No part of this paper may be reproduced without the permission of the authors. 


\title{
A new way to link development to institutions, policies and geography
}

\author{
Sudip Ranjan Basu ${ }^{\dagger}$
}

\author{
United Nations \\ Conference on Trade and Development, Geneva
}

First version, 14 October 2006

This version, 1 March 2008

\begin{abstract}
The paper aims to examine the role of institutions relative to economic policy and geography in explaining the differential level of development across countries over time. To that end, it attempts to construct a Development Quality Index (DQI) and an Institutional Quality Index (IQI) by using multivariate statistical method of principal components. It shows that (i) higher level of IQI along with economic policy and geography factors lead to a positive improvement in the level of DQI; and (ii) results remain robust for IQI and relatively robust for economic policy and geography even when it is compared across cross-section and panel data estimation for a set of 102 countries over 1980 to 2004. The results strongly indicate that institutions matter in the context of specific economic policy mixes and geography related factors illustrated by disease burden, etc. It demonstrates that relative influence of institutions varies across stages of development.
\end{abstract}

Key Words: Development, Institutions, Economic policy, Geography, Principal component, Instrumental variables, Panel data

JEL Classification Numbers: C3, O10, O57, P51, R11

${ }^{\dagger}$ I would like to express my sincere thanks to John Cuddy, A.L.Nagar, Lawrence R.Klein, M.Muqtada, Meghnad Desai, Pranab Bardhan, Khalil Rahman, Victor Ognivstev, Richard Baldwin, Jim O'Neill, Andrew Cornford, Sam Laird and Gayatrika Gupta for their insightful comments during preparation of this paper. Thanks are also due to participants at the UNCTAD Research Seminar. Part of the research was undertaken when author was a Ph.D. candidate at the Graduate Institute. The views expressed in this paper are those of the author and do not necessarily reflect the views of the United Nations Secretariat or its members. Any errors in this paper are those of the author.

E-mail: basu1@ hei.unige.ch, sudip.ranjan.basu@unctad.org

Fax: +412291700 44 


\section{Introduction ${ }^{1}$}

An increasing number of developing countries are gaining transition in economic growth and are able to raise level of human and social development. The key question however, even when the process seems to work well, is how to hasten and sustain the speed of economic growth, and turn such growth into high quality sustainable development.

North advocated the new institutional economists (NIEs) to claim that institutions are a primary cause of economic development and that development agenda should be redirected to "build" institutions as that of the standards of developed countries of today. ${ }^{2}$ In the words of North (1990): "That institutions affect the performance of economies is hardly controversial. That the differential performance of economies over time is fundamentally influenced by the way institutions evolve is also not controversial." The new institutional economists believe that stages of economic development are exogenously determined, or at best they influence development through institutions, by economic policy and geography.

This paper attempts to understand the process of development in the context of three major determinants as expounded in the literature, viz., institutions, economic policy measures and geography.

The NIEs argue, following North's arguments Acemoglu, Johnson and Robinson (2001) provided some of the influential empirical evidence to describe the importance of institutions. To address the issue of endogeneity, Acemoglu, Johnson and Robinson used settlers mortality (an instrument for institutions to control for endogeneity in 2SLS-IV regression specification) by using the dataset of European colonialists mortality rates of soldiers, bishops and sailors, and concluded that Europeans adopted better institutions where they faced low mortality rates, and vice versa. The empirical evidence showed that after controlling for the effects of institutions, the geography did not matter for economic performance. Acemoglu, Johnson and Robinson (2002, 2004) concluded that "Institutions as the Fundamental Cause of Long-Run Growth" (2004). ${ }^{3}$ Their findings were strengthened by Rodrik, Subramanian and Trebbi (2004), as they argued that "Institutions Rule: The primacy

\footnotetext{
${ }^{1}$ See Basu (2008) for the larger version of this paper in the UNCTAD working paper series.

2 Douglas North received Nobel Prize in Economic Science in 1993 "for having renewed research in economic history by applying economic theory and quantitative methods in order to explain economic and institutional change."

${ }^{3}$ See Knack (1997) for providing explanation on economic differences by institutional differences.
} 
of institutions over geography and integration in economic development" They further noted that the "quality of institutions "trumps" everything else." 4

Easterly and Levine (2003) demonstrated that institutions can explain only crosscountry variation in GDP per capita and concluded that "institutional quality seems to be a sufficient statistic for account for economic development." Similarly, Hall and Jones (1999) attributed the differences in "output per worker" due to differences in "institutions and government policies." To join this debate, Bardhan (2005) argued that perhaps institutions play an important role in determining economic performance, but a question still remains"Institutions matter, but which ones?" He proposed to look into two measures of institutional quality, namely, rule of law and weak political rights to regress not only on GDP per capita, but also on literacy and life expectancy. ${ }^{5}$ He found that rule of law was significant in explaining the GDP per capita, but not the level of literacy as opposed to weak political rights variable. This perhaps indicates the importance of other sets of institutional quality variables rather than concentrating on property rights based measures of institutional quality alone for the explanation of development. ${ }^{6}$

In some of the most cited papers in recent years on the relationship between trade policy, per se, and economic growth are probably that of Sachs and Warner (1995), Edwards (1998), Frankel and Romer (1999), Dollar and Kraay (2001, 2003) and Wacziarg and Welch (2003). The cross-country regression primarily suggests that countries that have opened up and taken robust trade policies are the ones growing faster than the others in raising economic performance. On contrary, there is still plenty of scepticism about the positive relationship between opening up and economic performance. ${ }^{7}$ Stiglitz (1999), Rodriguez and Rodrik (2000) and Muqtada (2003) raised questions about some of the above studies on economic growth and openness. Moreover, another concern now is about the quality of growth, rather than quantity per se. $^{8}$ In this context the role of social policies and better

\footnotetext{
${ }^{4}$ The indicator is taken Political Risk Service (PRS)-Group's International Country Risk Guide database.

${ }^{5}$ Two institutional indicators are taken from Kaufmann et al (2005) and Human Development Report of UNDP respectively.

${ }^{6}$ See Basu (2002; 2003a,b; and 2006) for further discussion and empirical evidence on the role of institutions to improve development within the background of economic policies and geography both at the national (India) and cross-country level.

${ }^{7}$ See Mussa (2000), Rodriguez (2006) for further discussion on economic integration, openness and growth relations.

${ }^{8}$. See Barro (2001) and World Bank (2000) for further discussion.
} 
institutional framework is getting at the centre stage of the development policies across the countries. The economic policy includes the trade-policy changes, effective industrial policy measures and appropriate macroeconomic policies and are considered the centrepiece of the so-called Washington Consensus for 'getting prices right'. ${ }^{9}$ On the contrary, Easterly and Levine (2003) showed a completely "no effects of policy" on development once they were controlled for institutions. Hence, the policy matters view in development has not got clean chit either. $^{10}$

How much does geography contribute to the explanation of the differences in crosscountry economic performance? A long time ago, Montesquieu (1748) initiated the discussions of geography view, by introducing climate theory to explain a lack of economic development. Diamond (1997) in "Guns, Germs and Steel", stressed that geography explains the dominance of Western Europe in modern times. He argued for the importance of geography and ecology to develop key institutions.

Gallup, Sachs, and Mellinger (1998) professed that one could show a critical role of geography in affecting economic performance after controlling for macro economic policies and institutions. McArthur and Sachs (2001) argued against the primary role of institutions, as "both institutions and geographically-related variables such as malaria incidence or life expectancy at birth are strongly linked to gross national product per capita."

Bloom and Sachs (1998) claimed that Africa's tropical environment could be seen as an obstacle to economic development. They also underlined that fact of high malaria incidence for their huge amount of reduction in annual economic growth rates. To assert more importance to malaria incidence and its devastating effect on human life, Gallup and Sachs (2001), and Sachs (2003a) put forward empirical evidence that it is not only economic development as measured by GDP per capita; also poverty is "intimately connected". 11

Masters and McMillan (2001) provided further empirical evidence to assert that climatic conditions could determine economic performance. Taking the argument further and deeper, Hibbs and Olsson $(2005,2004)$ described the key role of geographic and initial biogeographic conditions to help transition from agriculture to industrial development. Their

\footnotetext{
${ }^{9}$ This phrase has become synonymous to globalization. Williamson (2002) says: "Audiences the world over seem to believe that this signifies a set of neoliberal policies that have been imposed on hapless countries by the Washington-based international financial institutions and have led them to crisis and misery."

10 The "one-size-fits-all" recommendations of BWI's were discredited by many.

${ }^{11}$ See Glaeser et al (2004), Przerworski (2004) for further discussion on institutions and geography debate.
} 
cross-country results show that effects of geography and biogeography strongly explain the current level of economic development differentials even after controlling for institutions as measured by social infrastructure in Hall and Jones (1999). Sachs (2003a) declared that "Institutions Don't Rule: Direct Effects of Geography on Per Capita Income."12 All of these results and arguments are directed to showcase that geography matters for economic development, even when controlled for institutional quality and economic policies. ${ }^{13}$

So, the literature unambiguously shows how economic research in this area has been debating on the question of primacy role of factors in explaining the underlying forces of economic performance variations. The existing studies tend to contradict to announce the winner among so-called three prime contestants. We attempt to provide a conceptual framework for analysing these linkages in the broader context of development and institutional quality.

The paper is organised as follows: Section 2 outlines the interrelationships among institutions, economic policy and geography. Section 3 describes the methodology to measure DQI and IQI. The cross-section and panel data, including system-GMM, results along with the relevant discussions for the econometric model specifications are reported in Section 4. Section 5 concludes the paper.

\section{Conceptual framework}

The paper attempts to go beyond simple GDP per capita measure to account for the quality of life aspect of development, and also provides a broader measure of the explanatory variable, such as the institutional quality index. ${ }^{14}$

We propose to construct a new measure of development quality to account for the different dimensions of economic, health and knowledge of a country. This measure expands the dimension of the human development index, as DQI is supposed to provide, even, a broader-measure of development across countries. This intends to underscore the need to go beyond GDP per capita and/or HDI as a measure of development.

\footnotetext{
${ }^{12}$ Sachs (2003b) reminded that "Institutions matters, but not for everything."

13 Baldwin et al (2001) show how geography of growth takes-off in the backdrop of "Global Income Divergence, Trade, and Industrialization".

${ }^{14}$ See Basu, Klein and Nagar (2005) for further discussions on different dimensions of quality of life.
} 
One of the seminal works in quantifying development in a broader perspective was by Adelman and Morris (1967). They aimed to examine the interactions among the processes of social, economic and political change with the level and pace of development. Morris D. Morris (1979) constructed the Physical Quality of Life Index (PQLI) to measure the development quality and/or quality of life with some social indicators. Dasgupta and Weale (1992) in measuring quality of life advanced the concept with the inclusion of civil and political rights. And then United Nations Development Programme (UNDP)'s Human Development Index (HDI, 1990-2005) had brought together the production and distribution of commodities and the expansion and use of human capabilities in their measure. ${ }^{15}$

The proposed Development Quality Index (DQI) is constructed on the basis of three dimensions: economic, health, and knowledge. These three dimensions are supposed to evaluate the society's overall development level and quality of life. There are six indicators to measure the economic development of the people in the country: GDP per capita (in PPP international 2000 \$), Telephone lines, Television sets, Radios, Electric power consumption per capita, and Energy use per capita. Over the years, there seems to be a consensus that these indicators are key to economic success of countries.

In the health development quality dimension, we intend to identify the status of health in countries. We have selected five indicators to measure this dimension of the development quality index. The indicators are the following: Life expectancy at birth, Infant mortality rate, Physicians, Immunization of children, and $\mathrm{CO} 2$ emissions per capita. The $\mathrm{CO} 2$ indicator shows an environmental aspect, which may lead to degradation of health conditions. ${ }^{16}$

Finally, in the knowledge development dimension, four indicators are included. These indicators provide both the quantity and quality aspects of knowledge and/or human capital accumulation. The indicators are the following: adult literacy rate, primary school enrolment rate, secondary school enrolment rate and total number of years in schools. ${ }^{17}$ The idea here is to capture not only total literacy conditions, but also to see their components. Finally, we

\footnotetext{
15 See Anand and Sen (1994) on "Human development Index: Methodology and Measurement" for a comprehensive discussion of HDI, Sen (1999) for detailed discussion on development as freedom concept and related paradigm, and Sengupta(2000) on rights-based approach to development.

${ }^{16}$ The concept of Green Growth is now taking shape around the world to account for the environmental concerns.

${ }^{17}$ The Barro and Lee (2000) dataset shows the average years of schooling in the adult population (25 years of age and older).
} 
have selected 15 indicators to measure a composite index of development quality index (DQI). ${ }^{18}$

Moreover, we conceptualize the institutional quality into three dimensions to organize provide a new measure of institutional quality. The indicators are obtained from existing sources, but we use a new methodology to prepare a composite index by assigning statistical weights to these chosen indicators and grouped into three categories. ${ }^{19}$ Therefore, the new measure of aggregated Institutional Quality Index (IQI) is constructed to monitor and evaluate the quality of institutions among countries. Our institutional quality measure is based on three dimensions: economic, social and political.

There are now some widely used measure of institutional quality to capture institutional dimensions around the world. Perhaps, "Governance Matters IV: Governance Indicators for 1996-2004" as constructed by Kaufmann at al. (2005) of the World Bank, has now become the standard tool to measure institutional quality around the world. The governance indices are compiled from different sources and are put together. Some of the sources that go into constructing that index are the following: PRS Group-ICRG index, Freedom House's Economic Freedom Index, POLCON database, Polity IV project database and many others.

The dimension, economic institutional quality, is composed of eight indicators: legal and property rights (on an increasing scale of 1-10), bureaucratic quality (on a scale of 0-4 scale, 4 corresponding to the lowest level of bureaucracy), corruption (on a scale of 0-6, 6 corresponding to least corruption), democratic accountability (on a scale of 0-6 scale, 6 corresponding to the highest level of accountability), government stability (on an increasing scale of 0-12), law and order (on an increasing scale of 0-6), independent judiciary (on a binary scale of $0-1,1$ corresponding to greater independence), and regulation (on a scale of 1-10 scale, 10 corresponding to the lowest level of regulation).

The dimension, social institutional quality, is intended to represent rights and empowerment through the following indicators: press freedom (on an increasing scale of 13 ), civil liberties (on an increasing scale of 1-10), physical integrity (on a scale of 0-8, 8

\footnotetext{
${ }^{18}$ All the indicators that make up the DQI are self-explanatory in nature.

${ }^{19}$ See UNDPs publication "Sources for Democratic Governance Indicators" for the most comprehensive account of all the existing institutional quality indicators in the market. http://www.undp.org/oslocentre/cross.htm
} 
corresponding to the highest level), empowerment rights (on an increasing scale of 0-10), freedom of association (on an increasing scale of 0-2), women's political rights (on an increasing scale of 0-3), women's economic right (on an increasing scale of 0-3), and women's social rights (on an increasing scale of $0-3$ ). ${ }^{20}$

The dimension, political institutional quality, includes the following indicators: executive constraint (on a scale of 1-7 scale, 7 corresponding to the level of least constraint), democracy (on an increasing scale of 0-70), political rights (on an increasing scale of 0-10), polity (on a scale of $0-10,10$ corresponding to the highest level of democracy), lower legislative effectiveness (on a binary scale of $0-1,1$ corresponding to an effective lower level for the legislative process), upper legislative effectiveness (on a binary scale of 0-1, 1 corresponding to an effective upper level for the legislative process), and sub-federal independence (on a binary scale of $0-1,1$ corresponding to a higher level of decentralisation). There are thus 23 indicators in total for the three dimensions of IQI. (See Appendix Table A1 for list of indicators in DQI and IQI)

Geography is measured by an absolute value of the distance from the equator in degrees, latitude, that is scaled between 0 and 1 , where 0 is the equator), and other indicators such as climatic, ecological and incidence of malaria, while economic policy measures are captured by some of the key economic policy interventions such as macroeconomic stability policies to contain inflation; trade policies for removal of quantitative restrictions on imports, reduction in import tariffs to increase trade openness and integration to the world economy; other external sectors control policies to intervene in exchange rate determination; financial market policies for banking sectors, capital liberalization measures, credit market deregulation mechanisms; and domestic industrial policies of privatisation of the key state owned enterprises, removal of state sponsored subsidies; and flexible labour market policies, etc. So, the economic policy is measured by trade openness, inflation, exchange rate differential, credit market deregulation and capital liberalization measures). (See Appendix Table A2)

The issue of endogeneity is taken care of in this paper. In the case of institutions, the economic policies may also be influenced by income and institutions. Hence, there are possibilities of reverse causality. On the other hand, NIEs argues that geography is an

\footnotetext{
${ }^{20}$ See Swamy et al (1999) for discussion on gender and corruption.
} 
exogenous determinant of economic performance. However, the proponents of a geography hypothesis argue that geography can directly affect the human health and environmental conditions, and that would in turn influence economic conditions. ${ }^{21}$

As Sachs argues that the disease burden, as measured by malaria transmission and other diseases can not be taken exogenous anymore, as they are invariably affected by development and institutional quality. Therefore, for empirical treatment, we need to find out "good instruments" to tackle the endogeneity concern of institutions, economic policy, and geography-related factors. In this paper, we am not introducing any new 'instruments'. We make use of exiting instruments for institutions (European colonizer's settler mortality and Europeans ethnolinguistic fractions that combined English language speaking population, and other European language, such as French, German, Spanish, Portuguese, speaking population are two most widely used instruments now), economic policy (constructed trade share derived from a gravity-based approach of bilateral trade estimation), and geography (ecological and climatic conditions) for the 2SLS-IV (two stage least squares- instrumental variables) regression estimations to address endogeneity of the variables.

So, according to the above discussions, we need to test if, indeed, institutional quality is the only significant determinants of development. The proponents of economic policy measures and geography argue a close interrelationship among these factors in determining differential of variation among countries. Therefore, the testable hypothesis is:

Institutional quality (measured by an index IQI) is a significant factor relative to economic policy and geography in explaining quality of development (measured by an index $D Q I)$, but its relative significance depends on a country's stage of development.

Throughout this paper, with the two new measures of development (DQI) and institutions (IQI), we intend to explore thoroughly the above hypothesis. Furthermore, the paper helps to disentangle the complexities of development process by introducing DQI, and its interactions with institutions, economic polices and geography in this increasingly globalized world. ${ }^{22}$

\footnotetext{
${ }^{21}$ See Chong (2000) and Kaufman and Kraay (2003) on the causality between institutions and economic growth.

${ }_{22}^{2}$ See OECD (2001) and World Bank (2003)
} 


\section{Measuring Development and Institutions}

In this section, we propose two new measures, Development Quality Index (DQI) and Institutional Quality Index (IQI). Nagar and Basu (2002) developed a methodology to construct a composite index based on the multivariate statistical technique of principal component analysis. ${ }^{23}$ The key advantage of this methodology is the possibility to define a composite measure that is able to account for interactions and interdependence between the identified set of dimensions and variables to construct the DQI and IQI.

\subsection{Computational method of DQI and IQI}

We postulate DQI and IQI are, in fact, a latent variable, which cannot be measured directly in a straightforward manner. However, we assume that it is linearly determined by many exogenous variables say, $X_{1}, \ldots \ldots ., X_{K}$.

Let $Y=\alpha+\beta_{1} X_{1}+\ldots \ldots \ldots+\beta_{K} X_{K}+e$-------(1)

where $X_{1}, \ldots \ldots . ., X_{K}$, measured over countries is a set of total number of variables that are used to capture Y (DQI or IQI). For normalisation, the maximum and minimum values of these indicators are taken from world sample, so that we can trace out their relative rise over the period at the national level. In the case of regional level analysis, the maximum and minimum values are taken from countries own sample during the period under study.

Following normalization of exogenous variables, we construct principal components of $X_{1}, \ldots \ldots ., X_{K}$, which have the property that the first principal component $\left(\mathrm{P}_{1}\right)$ accounts for the largest proportion of total variation in all development quality variables, the second principal component $\left(\mathrm{P}_{2}\right)$ accounts for the second largest proportion of total variation in all development quality variables, and so on. If we compute as many principal components as the number of development quality variables, the total variation in all of them is accounted for by all principal components together. It is worthwhile to note that the principal components are mutually orthogonal. It is worthwhile to note that the DQI and IQI are a weighted sum of a normalized version of these selected variables, where respective weights are obtained from the analysis of principal components.

${ }^{23}$ See Klein and Ozmurcur (2002/2003) and United Nations (2005, 2007) for application of this methodology. 
The DQI or IQI can be shown as

$$
D Q I / I Q I=\frac{\lambda_{1} P_{1}+\cdots+\lambda_{K} P_{K}}{\lambda_{1}+\cdots+\lambda_{K}}
$$

Here weights are the eigenvalues of the correlation matrix of exogenous normalised variables. We have arranged them in descending order of magnitude as $\operatorname{Var} P_{1}=\lambda_{1}, \cdots, \operatorname{Var} P_{K}=\lambda_{K}$. Moreover, we assign largest weight $\lambda_{1} / \sum \lambda_{i}$ to $\mathrm{P}_{1}$ because it accounts for the largest proportion of total variation in all development quality variables. Similarly $\mathrm{P}_{2}$ has been assigned the second largest weight $\lambda_{2} / \sum \lambda_{i}$ because it accounts for the second largest proportion of the total variation in all the development quality and institutional quality variables, and so on.

In the case of Development Quality Index (DQI), we separately compute three dimensions of development quality: economic, health and knowledge, in line with above methodology. Once, we obtain three indices, we then again run the model to construct the DQI for each of the countries in the sample for the specific time point, say, t. Similarly, we construct three separate dimensions of IQI: economic, social and political, and then combine them again with the similar procedure to obtain index of institutional quality. The higher values of both indices indicate higher level of development and institutional quality respectively and the indices are comparable over time. ${ }^{24}$

\section{The empirical model}

The hypothesis is examined through the framework of the following basic equation:

$$
D Q I_{i}=\alpha_{1}+\alpha_{2} I Q I_{i}+\alpha_{3} E P O L_{i}+\alpha_{4} G E O G_{i}+\varepsilon_{i}
$$

where the dependent variable $D Q I_{i}$ is development quality index in country $i$ of the current sample; and three 'primary' explanatory variables are the following: $\mathrm{IQI}_{\mathrm{i}}$ is the Institutional Quality Index; EPOL $\mathrm{L}_{\mathrm{i}}$ is the trade/GDP ratio, an indicator of economic openness and attempts to integrate with the world economy; $\mathrm{GEOG}_{\mathrm{i}}$ is a measure of geography, which is the

\footnotetext{
${ }^{24}$ See Basu and Nagar (2004) for the statistical properties of this type of composite index as estimator of a single latent variable.
} 
absolute distance from the equator; $\varepsilon_{i}$ is a random error term; and the subscript $\mathrm{i}$ denotes country i.

Ordinary Least Squares (OLS) estimates of (3) were made with the use of combined time-series and cross-section data for the non-overlapping periods, 1980-1984, 1985-1989, 1990-1994, 1995-1999, and 2000-2004.

If it is assumed that $\mathrm{IQI}_{\mathrm{i}}$ and $\mathrm{EPOL}_{\mathrm{i}}$ are endogenous variables, there is reverse causation, which vitiates the assumption of the independence of these two indicators and the random error term, thus making the parameters in (3) estimated through OLS difficult to interpret. In technical terms the estimates of the parameters are biased, and the error will not disappear as the sample of observations increases, i.e. the estimates are also inconsistent. This problem is handled here through the method of two-stage least squares with instrumental variables (2SLS-IV). For this purpose, following Acemoglu, Johnson and Robinson (2001), $\operatorname{logSM_{i}}$, a measure of settler mortality, and following Frankel and Romer (1999), EPOLC $\mathrm{E}_{\mathrm{i}}$, an appropriately constructed trade share, are included as instruments assumed to contribute together with the exogenous variable, $\mathrm{GEOG}_{\mathrm{i}}$, to the determination of $\mathrm{IQI}_{\mathrm{i}}$ and EPOL $\mathrm{L}_{\mathrm{i}}$. We also employ other instruments of institutions to test the robustness of the result. Thus in the first-stage of the 2SLS-IV OLS estimates of $\mathrm{IQI}_{\mathrm{i}}$ and EPOL $\mathrm{i}_{\mathrm{i}}$ are made on the basis of the following two equations:

$$
\begin{aligned}
& I Q I_{i}=\beta_{1}+\beta_{2} \log S M_{i}+\beta_{3} E_{P O L C_{i}}+\beta_{4} G E O G_{i}+\varepsilon_{I Q I_{i}} \\
& \mathrm{EPOL}_{i}=\theta_{1}+\theta_{2} \mathrm{EPOLC}_{i}+\theta_{3} \log \mathrm{SM}_{i}+\theta_{4} G E O G_{i}++\varepsilon_{E_{\text {EPL }}}
\end{aligned}
$$

The resulting OLS estimates of IQI $\mathrm{I}_{\mathrm{i}} \beta_{1}+\beta_{2} \operatorname{logSM_{i}}+\beta_{3}$ EPOLC $_{\mathrm{i}}+\beta_{4} \mathrm{GEOG}_{\mathrm{i}}$. and of EPOL $_{i}, \theta_{1}+\theta_{2}$ EPOLC $_{i}+\theta_{3} \operatorname{logSM_{i}}+\theta_{4}$ GEOG $_{i}$, are then inserted in equation ( 1 ), removing the problem of the dependence of $\mathrm{IQI}_{\mathrm{i}}$ and $\mathrm{EPOL}_{\mathrm{i}}$ on $\varepsilon_{\mathrm{i}}$, the error term.

The results of the estimates for the two stages of 2SLS-IV carried out on pooled cross-section data for 1980-2004 are shown separately for three groups: all countries in the sample, after exclusion of countries belonging to EU10 and SEE\&CIS, and after exclusion of African countries.

As an alternative approach to addressing problems posed by the pooling of crosssection and time-series data as well as other estimation problems such as endogeneity, the 
techniques of modelling panel data can be employed. These techniques make possible the identification of changes through time in the way in which IQI and the other regressors influence DQI. They also have the advantage of allowing for the effects on estimation of such issues as unobserved country effects, biases due to omitted variables leading to unobserved heterogeneity, outliers, endogeneity, etc. and of producing more reliable estimates as the sample of observations and the number of degrees of freedom increase. ${ }^{25}$

The basic specification of the equation used for the estimation with panel data is as follows:

$$
D Q I_{i t}=\alpha_{i}+\beta_{1} I Q I_{i t}+\beta_{2} E P O L_{i t}+\varepsilon_{i t}
$$

where $\mathrm{DQI}_{\mathrm{it}}$ is development quality index in country $\mathrm{i}$ (for $\mathrm{i}=1,2, \ldots .102$ ) at time $\mathrm{t}$ (for $\mathrm{t}=1980-84, \ldots .2000-2004)$ of the current sample, $\alpha_{i}$ is an unobserved time- invariant countryspecific heterogeneity term, $\mathrm{IQI}_{\mathrm{it}}$ is the Institutional Quality Index; EPOL $\mathrm{L}_{\mathrm{it}}$ is a measure of countries economic policy, and $\varepsilon_{i t}$ is a random error term. Country-specific effects which are covered by GEOG in the OLS and 2SLS-IV regressions are now included in $\alpha_{\mathrm{i}}$. According to the hypothesis stated above that the signs of $\beta_{1}$ and $\beta_{2}$ are expected to be positive and significant.

If a simple pooled OLS-estimation procedure is applied to estimate equation (3), the model will not exploit all the panel structures, and the coefficient estimates will be inefficient and standard errors may be incorrect. The choice of approach to panel data depends on the assumptions made about $\alpha_{i}$ the variable representing the unobserved heterogeneity in the data. If it is assumed that $\alpha_{i}$ and the regressors may be correlated, then the appropriate estimation procedure is one of those for the fixed effects model (FEM). But if they can be assumed to be uncorrelated, the appropriate procedure is that for the random effects model (REM). Whether the FEM or the REM is preferred, the Hausman specification test can be used to check the statistical significance of the difference between parameters estimated on the basis of the two alternatives.

The framework of a dynamic model for panel data framework can also be used to investigate variation in parameters within a cross-section and through time. In recent

\footnotetext{
${ }^{25}$ See Baltagi (2002) and Wooldridge (2002) for detailed discussions on the panel data models.
} 
empirical literature two types of dynamic panel models have been used: the differenceGeneralised Method of Moments (GMM) estimator proposed by Arellano and Bond (1991) (henceforth $\mathrm{AB}$ ) and the system-GMM as proposed by Blundell and Bond (1998) (henceforth BB). In GMM specifications the estimator allows for the inclusion of lagged dependent variables among the explanatory variables, which takes care of unobserved country- specific heterogeneity and the endogeneity of other explanatory variables by introducing appropriate lagged variables to be used as instruments.

Following Arellano and Bond (1991), equation 5 can be re-specified as follows:

$\Delta D Q I_{i t}=\gamma \Delta D Q I_{i, t-1}+\beta_{1} \Delta I Q I_{i t}+\beta_{2} \Delta E P O L_{i t}+\Delta \varepsilon_{i t}$

where $\Delta$ is the first difference operator. Since the new error term $\Delta \varepsilon_{i t}$ is by assumption correlated with the lagged dependent variable $\Delta D Q I_{i, t-1}, \mathrm{AB}$ used the following instrumental variables: levels of DQI lagged two and more periods, and levels of the IQI and EPOL lagged two and more periods. It is intuitively difficult to account for the differences in IQI and EPOL on differences in DQI. But BB showed that when explanatory variables are persistent over time, lagged levels of these variables are weak instruments for the regression equations expressed in first differences. Thus BB is able to combine the first-differentiated GMM with the regressions in levels (system-GMM). This method reduces the potential biases associated with the estimators of the first difference-GMM of $\mathrm{AB}$ and produces consistent and efficient parameter estimates. ${ }^{26}$ The analysis is only carried out by using system-GMM only for dynamic panel models.

The results of their analysis, which regresses DQI on lagged DQI, IQI, political IQI, social IQI, economic IQI, EPOL which also includes now inflation, the differential between the official and black-market exchange rates, and measure of credit and capital-account liberalisation measure ${ }^{27}$.

\footnotetext{
${ }^{26}$ See Bond (2002) for an in depth analysis of dynamic panel models.

${ }^{27}$ The basic source of capital-account liberalization measures are taken from IMF's Annual Report on Exchange Rate Arrangements and Restrictions. This measure is created as follows: if a country is open in all the five years during the period, say 2000-2004, then assign score 1; if it is open for 4 years, assign score 0.8 , for 3 years 0.6 , and so on. 0 is assigned if country is closed in all the five years. So, the variable takes value from 0 (capital control- not capital-account liberalization) and 1 (no capital control- highest level of capital-account liberalization). See Basu (2007) for further discussion and use of this new measure.
} 
This paper is based on 102 countries as shown in Table A3, with 22 OECD countries. The list also shows that of 29 least developed and small-medium size economies as defined by United Nations and WTO respectively. This also includes 64 countries from AJR (2001) sample on settler mortality data. We have computed DQI and IQI for 102 countries for five time points: 1980-1984, 1985-1989, 1990-1994, 1995-1999, and 2000-2004. In the crosssection regression results, initially we obtained period wise OLS estimates. Then we make average of the five time points, to run the cross-country regressions. However, sample size differs due to (i) settler mortality rate data from AJR (2001) which has data on 64 countries, (ii) the whole sample (102 countries), and (iii) country groupings, like only developing countries (76 countries), and least developed countries and small-economies (29 countries).

In panel data regression, we use a five-yearly dataset for each of the 102 countries in each of the time points. This indicates a balanced panel dataset, with a total of 510 observations. Likewise in the cross-section case, the total numbers of observations vary in panel-data depending on the above classification of sample of countries. (See Table A4 and A5 for correlation between DQI, IQI and all exogenous indicators)

\section{Results}

This section discusses results both for cross-section and panel data estimation, including dynamic modelling. In section 5.1, initially, we discuss results from cross-section regressions; including OLS and two-stage least squares instrumental (2SLS-IV) results. Robustness analysis is also reported. ${ }^{28}$ In section 5.2, we discuss results from panel data analysis, both in static and dynamic framework. In a dynamic panel, we provide results for System-General Methods of Moments (System-GMM) of Blundell-Bond (1998) two-step procedure.

In Table A6, we present the results of this basic specification for each of the time points of the sample. In column 1 of panel 1, the results are shown for the period 1980-84, and in the last column we show the results after averaging the whole period, from 1980 to 2004. The OLS results clearly indicate that for the whole sample of 102 countries, in each of

\footnotetext{
${ }^{28}$ See Nagar (1959) for seminal work on 2SLS analysis. Nagar and Gupta (1970) for further discussion in a complete simultaneous system.
} 
the periods, the coefficient of IQI remains significant at the $1 \%$-level. ${ }^{29}$ The coefficient of the geography variable is positive and significant at the $1 \%$-level for all periods, and the whole period as well. The coefficient of the economic policy variable is positive but significant at $10 \%$ level. This goes with our hypothesis that IQI; policy and geography variables are positively correlated with DQI variable. In next three panels, we replicate the same specifications, but with three different dimensions of IQI, namely, political, social and economic. It is noteworthy that in all the period specifications, and for the whole period the results show a positive and significant sign for IQI dimensions.

Let us illustrate the case of India and Switzerland for a probable impact of IQI on DQI. If OLS is a causal relationship, then the size of the coefficient on IQI suggests its impact on DQI. For example, India has an IQI value in the sample of 7.34, and a DQI of 5.90. The regression coefficient from column 1 of Table A6 (with geography and the economic policy variable as explanatory variables) indicates that if India had an IQI closer to the IQI of 12.22 in Switzerland, then India would raise its level of DQI to about 16.88 (as against DQI of 5.90 in the sample, and of 35.55 of Switzerland), which indicates an improvement of over $186 \%$ from its current DQI value.

Coming to the coefficients of two other indicators, in these three different IQI dimensions, we provide evidence that although the geography variable continues to remain positive and statistically significant; however, the economic policy variable (as measured by trade/GDP ratio) is insignificant at the conventional confidence level in social and economic dimensions of IQI model specifications. We are not stretching far here the implications of this result, but one may tend to think that "stable" political institutions and/or good political institutions (of course, democracy is part of the process and inside the political IQI dimension) can provide better environments to carry out "good" economic policies and/or encourage deeper integration of its own economy to the rest of the world, for trade to foster economic performance subsequently. ${ }^{30}$

\footnotetext{
${ }^{29}$ Throughout this paper, we report robust standard errors and adjusted for clustering by country.

${ }^{30}$ See Giavazzi and Tabellini (2004) for not only discussion of positive relationship between economic reforms and performance in the context of political liberalization, but also the importance of sequencing of reforms matter.
} 
However, the OLS regressions results should not taken as causal or precise, as the coefficients are biased, and there is some reverse causality, omitted variable bias, measurements errors are persistent. Also there are the missing effects of country differences.

\section{1b 2SLS-IV regressions: IQI and EPOL as endogenous variables}

We report 2SLS-IV results where Panel A shows second-stage results of the equation (3) in which IQI and EPOL are the fitted value from the first stage regressions as in Panel B of estimated equation (2) as shown in Table A7. In panel A, column 1 shows the secondstage regressions results of the impact of IQI, geography and economic policy on development quality. The impact of IQI on DQI is now 3.57, and statistically significant at 1\%-level. This coefficient value is larger than OLS estimates. This indicates that there is attenuation bias from "measurement error" in the IQI variable. However, contrary to the finding of "wrong sign" of the geography variable, both in AJR (2001) and RST (2004), the estimates show that the geography variable has "right sign" but is insignificant. This may indicate that for development quality, going beyond the simple measure of GDP per capita, geography may have a positive impact. ${ }^{31} \mathrm{We}$ intend to show further results to discuss this later. Furthermore, the economic policy variable is also insignificant in the first specification, but it has "right sign" as we expected. In panel A, in the next column, we excluded from the sample Neo-Europe countries (Australia, New Zealand, Canada and USA). The result on IQI does not change much, but the EPOL is now significant at the $10 \%$-level. The geography variable shows again positive sign in this specification. This indicates the robustness of our specification and importance of three variables. In the next column, we excluded Africa from the sample, and find that IQI coefficient is 3.20, and so are the sign and significance of geography and the economic policy variable. The fourth column excludes both neo-Europe and Africa from the sample. Now the coefficient on IQI rises to 3.27 and geography and policy variables are also highly significant in this sample.

We present results from the first-stage regressions in Panel B. Instruments have the expected sign for the endogenous variables. For example, in the case of ex-colony sample, settler mortality has a negative and statistically significant effect on IQI, so is the constructed trade share on the EPOL variable. The coefficient of geography is positive and statistically

\footnotetext{
${ }^{31}$ If a country is far from equator, in temperate zones rather in tropics, economic performances increase.
} 
significant in the IQI endogenous variable. This is consistent with the findings of AJR (2001), and RST (2004). Two other specifications are almost similar. It indicates that the instruments chosen for IQI and EPOL are valid and sensible.

The Table also reports key diagnostic tests of 2SLS-IV regression estimates both for Panel A and B. In this model estimation, there are two endogenous variables and two instruments; hence, it is a case of exact identification. However, over-identification is a desirable property because it increases the efficiency of the estimates and allows for overidentifying restrictions tests (Sargen-Hansen $\mathrm{J}$ test). Later in the analysis of further results, we include more instruments than endogenous variables, and show the over-identifying restrictions tests. We also provide statistics on weak instruments. The F-statistics for firststage regressions for IQI and EPOL show (in ex-colony) are about 10 as suggested by Staiger and Stock (1997). ${ }^{32}$ However, in the case of specification without Africa, and without neoEurope and Africa in the sample, instrument for EPOL and IQI show statistic values well below threshold values that may raise some degree of concern over their validity in this particular group of country specifications. However, settler mortality seems to be an appropriate instrument for IQI in all the model specifications. Next, we report a Durbin-WuHausman test for endogeneity of IQI and EPOL. The null of exogeneity is rejected overwhelmingly in all the specifications at the $1 \%$-level indicating that they are, indeed, endogenous variables. For the Heteroskedasticity test, we report BreuschPagan/Godfrey/Cook-Weisberg tests in the presence of heteroskedasticity in an OLS regression, under the null of no heteroskedasticity. The results show that in first two specifications, the null is rejected at $1 \%$ and $10 \%$-levels, but not in the last two specifications. Then we report in Panel B, Shea (1997) diagnostic tests for determining the strength of the instruments in the case of multiple endogenous variables, and take into account inter-correlations among instruments. The Shea $\mathrm{R} 2$ is relatively higher in all the specifications, and is relatively higher in the last two sample specifications. ${ }^{33}$

So, the overall results in Table A7 indicate that although IQI is influential in explanation of the variations in DQI, the importance of geography and economic policy are

\footnotetext{
${ }^{32}$ The rule of thumb is that for a single endogenous variable, the F-statistics should be at least 10 to satisfy strength for the instrument..

${ }^{33}$ See Baum et al. (2003) for excellent discussion of 2SLS estimation.
} 
still well intact. This paper attempts to unlock their inter-linkages by introducing different instruments, sample groups, and panel data estimation.

We make use of larger sample of countries, in line with the argument presented by Hall and Jones (1999), where instruments for IQI are the following: fraction of population speaking other European language (eurfrac), and fraction of population speaking English (engfrac). We also report results for three dimensions of IQI in Table A8. In column 1, we report the coefficient of IQI, GEOG and EPOL on DQI. The IQI is significant and positive. The coefficient of IQI is smaller though in this large sample compared to table A7 results. Once again, we find that the geography variable is positive and significant, and so as the economic policy variable.

In the next three columns, we estimate three IQI dimensions on DQI along with the GEOG and EPOL variables. In all these specifications, we find that the economic IQI variable in column 4 has the largest coefficient compared to political and social IQI dimensions. We also find that geography and the economic policy variable are positive and significant. Hence, these results again go against the results of AJR (2001) and RST (2004). Perhaps, it indicates to the fact that policy matters and geography matters for overall level of development quality, which may not necessarily be a case in the current level of GDP per capita.

Moreover, all the diagnostics tests for weak instruments, and the Sargen-Hansen J test for over-identifying restrictions pass the test, as the $\mathrm{p}$ value is always higher than 0.05 , which means that the instruments are valid, exogenous and do not belong in the set of explanatory variables in this specification. This is really assuring for the strength of instruments. ${ }^{34}$ In first-stage regressions, the F-test value is greater that 10 suggesting that the instruments are well correlated with the endogenous variable in all the model specifications. Hence, the diagnostics tests seem to work well for all three dimensions of IQI as well.

We present robustness checks of our analysis by using both the settler mortality sample of ex-colonies without neo-Europe countries and two instruments of Hall and Jones (1999) in line with specifications in table A8. In Table A9 of column 1, we add regional

\footnotetext{
${ }^{34}$ The use of these instruments should not be interpreted as though these countries were in need again of going back to be colonized by Europeans and change their geographic position.
} 
dummies with basic specification. The coefficient of IQI is highly positive and significant as in column 2 of table 9 and also the size is larger in this specification. The coefficients of geography and economic policy are positive and are insignificant at 10\%-level. But the regional dummies are not statistically significant either. We use Hadi (1992) procedure to detect outliers in the estimation, and dropped the outlier countries from the sample, and reestimated the model. ${ }^{35}$

In the next four specifications, we include French legal origin dummy, followed by religion, language and ethnic fractionalization variables. Alesina et al (2003) introduces these three fractionalization variables, and we make use of this in our specifications. The religion variable is negative but is not statistically significant, while the language variable is significant and positive; and the ethnic variable is insignificant, in this ex-colony sample. The whole sample make use of Hall and Jones (1999) instruments, we find that the religion coefficient and language coefficient are positive, and ethnic is negative. In their paper Alesina et al (2003) noted that the religion coefficient does not follow any pattern when it is used to explain GDP growth, but language and ethnic coefficients are negative. However, we tend to believe that heterogeneity of linguistic and ethnic fractionalization may work well under a democratic setting that would eventually spur economic development. ${ }^{36}$ Otherwise, IQI coefficients remain highly significant across all the different specifications with inclusion of additional variables.

Then, we include additional geography variables, as has been used in the literature, to test the robustness of results in Table A10) The objective here is to cross check to all if geography, as an exogenous variable -like climatic condition, proximity to market, etc, plays a role in influencing development quality other than through institutional quality. We run these model specifications by using Hall and Jones (1999) instruments for the whole sample of 102 countries. $^{37}$ In all the specifications of Table A10, I drop two influential outlier countries, namely, Japan and Singapore, from the sample by using the Hadi (1992)

\footnotetext{
${ }^{35}$ We note the outlier countries in the tables.

${ }^{36}$ In Basu, Fan and Zhang (2006), we argue that in a democratic society like India, the development strategies tend to grow in a balanced manner because of different interest groups and fractionalization, while it is not the case in a society like China, which is highly homogeneous (0-1 scale with 1 highest fractionalization. The figure is 0.15 for China and 0.42 in India).

${ }^{37}$ Because of some missing variables of geography related variables for the set of countries in our sample, the estimation does not show all the countries of the sample.
} 
procedure. ${ }^{38}$ Column 1 reports the basic specification with 'landlocked' dummy, which enters in the second-stage regressions with negative sign but is insignificant. Then we add a 'tropical' variable, the percentage of a country's land area in the tropics, and it enters with a negative sign but insignificant, as well. Following Masters and McMillan (2001), we use two key climatic variables: area under frost and days under frost. They argue that tropical countries face a disadvantage because of the absence of winter frost, and we show that their argument is worth noting. Both variables enter with positive coefficients and later one is significant at the $1 \%$-level. This result contradicts the one found by Rodrik, Subramanian and Trebbi (2004) to explain the GDP per capita only. Then by adding mean temperature of a country, and, as expected, it has a negative sign but insignificantly enters into the equation. Following, Sachs (2003), we add a variable to measure the share of a country's population in temperate ecozones. To estimate the impact of country's proximity to sea, we enter, following Sachs (2003) in the equation, the proportion of land area within $100 \mathrm{~km}$ of area of the seacoast. It turns out to be positive in the second-stage regressions. Finally, after adding the endowment of hydrocarbons per capita, the findings show results similar to those of Gallup, Sachs, and Mellinger (1998), that of positive and significant effects on development quality. In all these cases, the results indicate expected signs of the variables, which simply imply that climatic conditions matter, in some varying degree though, for development quality. This table points that IQI, the original geography variable, and the economic policy variables remain significant in all the different model specifications, and by adding other geographical and climatic condition variables actually do matter in explaining the differences in development quality, as was rejected in earlier studies of Acemoglu, Johnson and Robinson (2001), Easterly and Levine (2003) and Rodrik, Subramanian and Trebbi (2004).

\section{1c 2SLS-IV regressions: IQI, EPOL and Geography as endogenous variables}

In this section, we argue following Sachs that disease burden, as measured by risk of malaria transmission; is a key geography related factor that matters for variations in development quality. McArthur and Sachs (2001) noted "both institutions and geographically-related variables (such as malaria incidence or other health indicators) play a role in determining GNP per capita." In this spirit, we show, indeed, geography related-

\footnotetext{
${ }^{38}$ Easterly (2004) observed that extreme observations in the growth regression adversely affects the results.
} 
malaria incidence-affects development quality even after controlling for institutional quality and economic policy variables. There are two malaria-incidence related variables: (i) mal94p is the proportion of each country's population that live with risk of malaria transmission based on 1994 WHO world map of a malaria risk database; and (ii) malfal is the proportion of population that live with risk of transmission of the fatal species, plasmodium falciparum. Then to control for a reverse causality from DQI to disease burden, we use the set of instruments as proposed by McArthur and Sachs (2001). ${ }^{39}$

In Table A11 and Table A12, we show the results for the Acemoglu, Johnson and Robinson (2001) sample with settler mortality as an instrument for IQI and for the whole sample with Hall and Jones (1999) instruments of IQI. Furthermore, we also present three dimensions of IQI, along with an economic policy measure and malaria incidence variables. Column 1 of Table A11 shows that IQI is positive and significant, while economic policy and malaria variables have 'right signs' but are insignificant. Now, in the case of a political IQI variable, the malaria incidence variable is negative and significant; and the economic policy measure is significant at the $10 \%$-level. The result holds in social and economic dimensions of IQI as well for the malaria variable (for malfal variable too), but the economic policy variable is insignificant. I find same pattern of signs and significance level with the whole sample. We also report at the bottom of the table the entire set of diagnostic tests and they pass all the conventional tests. (Appendix Table A12).

To do further robustness checks of these results, we subdivided the countries into two groups, developing countries, and least developed and small-medium size economies. We include here only two malaria related variables after controlling for IQI and its dimensions. ${ }^{40}$ The results clearly indicate here that malaria risk matters for development quality, as in the IQI as argued by Sachs and others. ${ }^{41}$ (Appendix Table A13)

\footnotetext{
${ }^{39}$ Sachs (2003) used malaria ecology (me), ecology-based variable that could be predictive of malaria risk, as an instrument for malaria risk.

${ }^{40}$ In Sachs' specifications, he looked only at the malaria along with an institutional variable. I drop South Korea in all these specifications by using Hadi (1992) procedure.

${ }^{41}$ It may be noted that the size of coefficients of IQI's decline once I divide countries in sub-sample in line with their stages of development.
} 


\section{1d 2SLS-IV regressions: IQI, 'other' EPOL and Geography as endogenous variables}

In Section 2.3, we introduced the discussions on the role of economic policy and its impact on development quality. In sub-sections 4.1a to 4.1c, the trade/GDP ratio was considered as a measure of overall economic policy (EPOL) of a country. The significance of coefficient of EPOL (expected to be positive) differs across different specifications and country groupings. In this section, we introduce some other economic policy variables, such as macroeconomic policies, trade and exchange rate policies, and financial market policies etc. The question is: do these economic policies matter after controlling for IQI and geography?

We introduce five different measures of economic policy variables, which have been discussed and used widely in the macro and international finance literature as determinants of GDP per capita/growth rates. These economic policy measures are the following: inflation, number of years a country is open according to the Sachs and Warner (1995) trade-openness measure $^{42}$, exchange rate differential (official vs. black market premium), ${ }^{43}$ credit market deregulations, ${ }^{44}$ and IMF capital market liberalization measure. First, following Easterly and Levine (2002), we consider these economic policy measures as exogenous, meaning they affect directly the level of economic development as we ignore any reverse causality steaming from higher development quality to better economic policies. Secondly, we consider these policies as endogenous, and we use instruments to control for reverse causality, and results are reported for Acemoglu, Johnson and Robinson (2001) sample. ${ }^{45}$

In the exogenous economic policy columns, we introduce the variables one by one in the model specification with IQI and malaria risk (geography) as two control variables. In

\footnotetext{
${ }^{42}$ This is a dummy variable ( 1 open and 0 closed) which classified an economy as closed if it is closed according to any one of the following five criteria during the decade of the 1970s or 1980s: (i) its average tariff rate exceeded $40 \%$, (ii) its non-tariff barriers covered more than $40 \%$ of imports, (iii) it had a socialist economic system (iv) it had a state monopoly of major exports, or (v) its black-market premium exceeded $20 \%$.

${ }^{43} \mathrm{~A}$ measure of exchange rate policy, which exits to ration foreign currency in the domestic economy. Hence, under, certain domestic economic condition, this may undermine resource-allocation and hamper economy. The data is from Freedom House, in a 0-10 scale, with 10 to countries without a black-market exchange rate; i.e., those with a domestic currency that is fully convertible without restrictions, and 0 rating is given when the black market premium is equal to, or greater than, $50 \%$.

44 The data is from Freedom House, which includes five factors: Ownership of banks, competition, extension of credit, avoidance of interest rate controls and regulations that lead to negative real interest rates, and Interest rate controls; in a $0-10$ scale, with 10 to countries with least regulations.

${ }^{45}$ We follow Rodrik, Subramanian and Trebbi (2004) and Sachs (2003).
} 
column 1 , the inflation coefficient is negative and significant at the $10 \%$-level. ${ }^{46}$ This shows that inflation, considered exogenous, have some negative influence on development quality. In this case, malfal variable is not significant any more, but has the right sign. In the following specification, we added the number of years a country was open during 1960-1995, and it shows openness to international market had positively influenced the development quality. The remaining columns report three other economic policy measures-related to less market distortion as measured with the difference of black market to official exchange rate, credit market deregulations, and capital liberalization measures enter the specifications with positive signs but are insignificant. Finally, in all the specifications IQI remains significant at the $1 \%$-level and the size of the coefficients do change much with the introduction of different economic policy variables. We also find that in the second-stage, the malaria risk variable- enters with negative sign, but is insignificant. In the bottom of the table, we report the entire set of different diagnostics test as we discussed previously, and all of them pass the test. Now, we consider economic policy as endogenous in our model specifications. Once again, except for openness, none of the four variables is significant in the specifications. However, the capital liberalization measure is now showing a negative sign. As we found previously, IQI remains positive and significant in all these specifications. ${ }^{47}$ (Appendix Table A14)

In sum, we find that in the exogenous policy case, the monetary policy of containing the inflation rate has a negative and significant coefficient, and so it is for the trade openness measure. Then, in the case of endogenous economic policy, only the trade openness variable remains positive and significant. ${ }^{48}$ With the above sets of results, we observe that in crosscountry regressions by averaging the data figures over the past two decade period shows influence of policy interventions, but significance differs across specifications, country groupings indicating stages of development, as well as effectiveness of different economic policy interventions. ${ }^{49}$

\footnotetext{
${ }^{46}$ We excluded countries with more than $100 \%$ inflation rate from the sample.

${ }^{47}$ These results broadly hold for the whole sample. We used the Acemoglu, Johnson and Robinson (2001) sample to follow the implications of the Easterly and Levine (2002) paper.

${ }^{48}$ The above results do not necessarily follow the finding of Easterly (2004), as he found not much importance of policies after controlling for institutions.

${ }^{49}$ See Basu and Das (2008) for further results of development and institutions in non-parametric analysis. The results from the parametric analysis of this paper do hold in the non-parametric approach as well.
} 


\subsection{Panel data results}

In this section, we estimate the panel data model which combines crosssection and time series data.

\section{2b Panel data regressions with institutions and economic policy measure}

We report both the pooled OLS and fixed effects estimates. (Appendix Table A15) In the first four columns, we added time-invariant geography variable as before in cross-section (latitude), along with IQI and EPOL (as measured by trade/GDP ratio for pooled OLS model. We have also reported three dimensions of IQI to explain the variation in development quality. In all the different IQI specifications, we find that all the three dimensions of IQIs are positive and significant at the $1 \%$-level. However, the size of the coefficients estimates on IQI's is now much lower, as predicted by the theory. As described in the literature, we should not take these pooled OLS estimates seriously, however.

In the next four columns, we estimated equation (3) with a fixed effects model. In the bottom of the table, the Hausaman specification test clearly rejects the null hypothesis, meaning that model should be fixed effects as against random effects specifications. The Breusch-Pagan test also rejects the null hypothesis to favour the OLS model is random effects. OLS estimates are biased-upwards, so the fixed effects estimates on IQI coefficients and EPOL coefficients are much smaller, but they are all still significant.

The panel corrected standard errors are used to estimate the equation (3). (See Appendix Table A16) The results show clearly that the model estimated after adjusting the standard errors and the size of coefficients have been reduced as compared to OLS estimations. All the coefficients enter with right sign, though, and they are highly significant. And then in the next four columns, we use FGLS estimation in the presence of panel specific AR (1) autocorrelation, and heteroskedasticity across panels with no cross-sectional correlation. So, after considering the panel specific autocorrelation process, we find that the size of the coefficients have been drastically reduced without changing sign and level of significance. ${ }^{50}$

\footnotetext{
${ }^{50}$ We run the model specification in the sample for developing countries only, as they have made most of the policy changes over the past two decades.
} 


\section{2c Panel data regressions with institutions and 'other' economic policy measures}

We use panel regression by introducing other economic policy measures in the specifications (Appendix Table A17). For this developing country sample, we report only fixed effects and FGLS-AR (1) specifications. In column 1, with the introduction of inflation rate with IQI, and the coefficient for inflation is negative and significant. The Hausman specification test favours the fixed effects model (as the null is rejected at $12 \%$-level). In the next three columns, we show results for three other economic policy measures, and all of them show positive sign and are significant. In column 5, we added all the economic policy measures with IQI. The size of coefficient on IQI remains almost unchanged with 5\%-level of significance, and inflation and IMF capital liberalization measures are statistically significant. This indicates a negative impact of inflation on development quality, and so is a positive effect of the capital liberalization measure on development quality. These results follow as well in FGLS-AR (1) specifications, but now the size of coefficients has increased with the corresponding decline in standard errors.

\section{2d Dynamic Panel data regressions: System-GMM}

For the system-GMM, we use equation (6) with the proposed additional specifications as discussed above by BB. This procedure, however, can be implemented by either the onestep estimator or the two-step with homoskedasticity of the standard errors. The two-step procedure faces a problem of over-fitting bias because the number of instruments is often too large with respect to the number of groups. Although, the one-step procedure does not have this problem, but the estimator is less efficient. We report the two-step estimator with heteroskedasticity consistent standard errors, which are based on the finite sample adjustment of as proposed by Windmeijer (2005).

Under the system-GMM procedure, we show results both for the whole sample and then specifically for developing countries. (Appendix Table A18) In column 1, we once again obtain positive significant coefficient on IQI as in all other previous model specifications. The trade/GDP share (EPOL) is positive and significant, while coefficients of inflation are positive, and so are the rest of the economic policy variables, but other economic policy variables are insignificant. In the next specification, we include political IQI variables as explanatory variables, and find similar results. The two other specifications, with 
social and economic IQI, give similar results, with two exceptions: inflation rate is still positive and significant, and so is the credit market deregulation variable. ${ }^{51}$

In the next four columns, we present results for the developing countries sample as a robustness check in the system-GMM case, and to account for stages of development argument of the sample. In the basic specification to explain the variance in DQI, the results show that EPOL and other economic policy variables, apart from IQI being significant at $1 \%$-level, credit market deregulation variable is positive and significant at $10 \%$-level and IMF capital liberalization measure is positive as well, but insignificant; and so is the EPOL variable. In the next column, we estimate the model with a political IQI variable, which shows the expected sign as before. The EPOL variable has 'wrong sign' now, as does the credit market deregulation variable; but is both insignificant. The inflation variable is negative and significant. In social IQI specification, apart from inflation being negative and significant, the credit market deregulation coefficient enters the model with negative and significant sign. Finally, with the economic IQI variable, none of the economic policy variables enters the equation with significant sign, and EPOL has 'wrong sign'.

By looking at the Sargen-Hansen $\mathrm{J}$ statistic test for over-identifying restrictions for two sets of sample, the results reported at the bottom of the table, suggest not to reject the null hypothesis, that implies that instruments used both in difference and level equations are valid for the endogenous model. Similarly, a first-order correlation AR (1) test rejects the null hypothesis and second-order AR (2) tests fail to reject null hypothesis in all the cases, meaning no higher order auto-correlation exists in the model, which clearly support the validity of the model specifications.

To sum up all the results from OLS to system-GMM, the institutional quality index (IQI) is robust across models in sign and significance level in explaining the level of development quality index (DQI). I find results to support the importance of economic policies and geography (and disease burden) to have 'right signs' and are significant, as key determinants of DQI, with some degree of variation in their significance across country groupings, indicating the relevance of accounting for stages of development in the analysis.

\footnotetext{
${ }^{51}$ The inclusion of lagged value of DQI as one of the explanatory variables captures persistence in DQI. The highly positive and significant coefficient indicates that the level of DQI has persisted since the 1980s in the sample.
} 


\section{Conclusions}

In recent years, following North's idea of institutions matter, various authors have concluded differently to explain the differential level of economic performance by crosssection analysis. Given this background, this paper provides evidence that in this increasingly globalized world, economic policy matters as do the geography and disease burden (and ecological conditions). The results of this paper seem to suggest strongly that both from the cross-section and panel-data analysis, the institutions, geography and economic policy play strong roles in explaining differential levels of development, although their relative significance in explaining DQI depends on the stages of development of a country.

So, the results in this paper indicate that institutions matter in the context of specific economic policy mixes, and geography related factors illustrated by disease burden, etc. The evidence demonstrates that relative influence of institutions varies across stages of development. Development quality is a complex phenomenon, and different factors are interrelated and help build up the process to work efficiently. The institutions can not be set up overnight, so that interventions to account for institutional development. As institution supporting economic activities grow stronger, the need for and role of policy interventions are expected to diminish. The institution building is no doubt a critical factor to make markets act smoothly, but we ought to understand the national level characteristics and their domestic concerns. This makes a case for these countries to have significant policy space. ${ }^{52}$

A policy implication is that we can't give generalized global solutions to address the local problems. We can, at best, provide a sense of an overall direction. The role of institutions with development agenda and strategies should be rooted in specific conditions and circumstances of developing countries.

\footnotetext{
${ }^{52}$ Dixit (2005) described: "In reality, each case of development failure may have multiple causes acting simultaneously. ....The ultimate aim would be to find a complex cause, or a syndrome...we are unlikely to get a situation where causes can be discerned from syndromes quite so well, but this gives us an ideal to work toward."
} 


\section{Appendix Tables}

Table A1: Development Quality Index (DQI) and Institutional Quality Index (IQI): Definition and Sources of Indicators

\begin{tabular}{|c|c|}
\hline$\underline{\text { Economic DQI }}$ & Economic IQI \\
\hline GDP per capita (PPP, \$ international 2000) & Legal and property rights ${ }^{3}$ \\
\hline Telephone mainlines (per 1,000 people) & Law and Order ${ }^{1 \mathrm{a}}$ \\
\hline Television sets (per 1,000 people) & Bureaucratic Quality $^{1 \mathrm{a}}$ \\
\hline Radios (per 1,000 people) & Corruption $^{1 \mathrm{a}}$ \\
\hline Electric power consumption (kwh per capita) & Democratic Accountability $^{\text {la }}$ \\
\hline \multirow[t]{3}{*}{ Energy use (kg of oil equivalent per capita) } & Government Stability $^{1 \mathrm{a}}$ \\
\hline & Independent Judiciary $^{2}$ \\
\hline & Regulation $^{3}$ \\
\hline Health DQI & Social IQI \\
\hline Life expectancy at birth, total (years) & Press Freedom ${ }^{3}$ \\
\hline Mortality rate, infant (per 1,000 live births) & Civil Liberties $^{3}$ \\
\hline Physicians (per 1,000 people) & Physical Integrity Index ${ }^{4}$ \\
\hline Immunization, DPT (\% of children ages $12-23$ months) & Empowerment Right Index $^{4}$ \\
\hline \multirow[t]{4}{*}{ CO2 emissions (metric tons per capita) } & Freedom of Association $^{4}$ \\
\hline & Women's Political Rights $^{4}$ \\
\hline & Women's Economic Right ${ }^{4}$ \\
\hline & Women's Social Right $^{4}$ \\
\hline Knowledge DQI & Political IQI \\
\hline $\begin{array}{l}\text { Literacy rate, adult total (\% of people ages } 15 \text { and } \\
\text { above) }\end{array}$ & Executive Constraint $^{6}$ \\
\hline School enrolment, primary (\% gross) & Political Rights $^{3}$ \\
\hline School enrolment, secondary (\% gross) & Index of Democracy $^{5}$ \\
\hline \multirow[t]{6}{*}{ Total number of years in schools $^{1}$} & Polity Score $^{6}$ \\
\hline & Lower Legislative $^{2}$ \\
\hline & Upper Legislative $^{2}$ \\
\hline & Independent Sub-federal Units $^{2}$ \\
\hline & \\
\hline & \\
\hline
\end{tabular}

Note. For DQI, data obtained from the World Development indicators CD-ROM 2006, World Bank;

and ${ }^{1}$ Barro and Lee 2000 dataset, ${ }^{1 a}$ PRS Group (2005) ICRG database; ${ }^{2}$ POLCON Henisz Dataset; ${ }^{3}$ Economic Freedom Index dataset, Freedom House; ${ }^{4}$ CIRI Human Rights Data Project; ${ }^{5}$ PRIO Dataset; ${ }^{6}$ Polity IV Project 
Table A2: List of all other variables in the analysis

\begin{tabular}{|c|c|}
\hline \multicolumn{2}{|c|}{ List of variables } \\
\hline Trade to GDP ratio ${ }^{10}$ (EPOL) & $\begin{array}{l}\text { Adult European settler mortality rates in the early } 19^{\text {th }} \\
\text { century(log of, annual deaths per } 1000 \text { population })^{1} \text { (smajr) }\end{array}$ \\
\hline Fraction of English speaking population ${ }^{2}$ (engfrac) & $\begin{array}{l}\text { Proportion of population at risk of falciparum malaria } \\
\text { transmission in } 1994^{6} \text { (malfal) }\end{array}$ \\
\hline $\begin{array}{l}\text { Fraction of other European language speaking } \\
\text { population }^{2} \text { (eurfrac) }\end{array}$ & $\begin{array}{l}1987 \text { mean annual temperature in degree } \\
\text { celsius }^{6}(\text { meantemp) }\end{array}$ \\
\hline Distance in absolute value of latitude ${ }^{2}$ (geog) & Share of population in temperate ecozones ${ }^{6}($ kgtemp$)$ \\
\hline Linguistic fractionalization index ${ }^{3}$ (language) & $\begin{array}{l}\text { Malaria ecology combines temperature, mosquito } \\
\text { abundance, and vector specificity }{ }^{6}(\mathrm{me})\end{array}$ \\
\hline $\begin{array}{l}\text { Ethnic fractionalization index measures of ethnic } \\
\text { heterogeneity }^{3} \text { (ethnic) }\end{array}$ & $\begin{array}{l}\text { Proportion of land area within } 100 \mathrm{~km} \text { of the sea, } \\
\text { coast }^{6}(1 \mathrm{t} 100 \mathrm{~km})\end{array}$ \\
\hline Religious fractionalization index ${ }^{3}$ (religion) & Sachs and Warner openness measure (Updated) ${ }^{7}(\mathrm{sw})$ \\
\hline & Constructed openness measure ${ }^{8}$ (epolc) \\
\hline $\begin{array}{l}\text { Dummy variable } 1=\text { population is predominantly } \\
\text { protestant(protestant) }\end{array}$ & Hydrocarbon production per capita ${ }^{5}$ (lenerg) \\
\hline $\begin{array}{l}\text { Dummy variable } 1=\text { population is predominantly } \\
\text { catholic(catholic) }\end{array}$ & $\begin{array}{l}\text { Dummy variable }=1 \text { if a war during } 1960 \text { s to } \\
1980 \mathrm{~s}^{9}(\text { ewardum })\end{array}$ \\
\hline $\begin{array}{l}\text { Dummy variable } 1=\text { population is predominantly } \\
\text { muslim(muslim) }\end{array}$ & $\begin{array}{l}\text { Period of national independence. }=0 \text { if independence before } \\
1914,=1 \text { if independence between } 1914 \text { and } 1945,=2 \text { if } \\
\text { independence between } 1945 \text { and } 1989 \text {, and }=3 \text { if after } \\
1989^{9} \text { (state) }\end{array}$ \\
\hline $\begin{array}{l}\text { Proportion of land with }>5 \text { frost-days per month in } \\
\text { winter }^{4} \text { (frstarea) }\end{array}$ & Log annual Inflation ${ }^{10}(\operatorname{lninf})$ \\
\hline $\begin{array}{l}\text { Average number of frost-days per month in } \\
\text { winter }^{4} \text { (frstday) }\end{array}$ & Exchange rate differential (Official vs BMP) ${ }^{12}$ (ome) \\
\hline Percentage of tropical land area ${ }^{5}$ (tropical) & Credit market regulation ${ }^{12}(\mathrm{cmr})$ \\
\hline Dummy variable $1=$ countries access to sea $^{5}$ (access) & IMF capital control measure ${ }^{11}(\mathrm{imfc})$ \\
\hline $\begin{array}{l}\text { Proportion of population live with risk of malaria } \\
\text { transmission in } 1994^{6}(\text { mal94p) }\end{array}$ & Sachs-Warner \# years country open in $1960-95^{7}$ (yearsopen) \\
\hline
\end{tabular}

Note: Code of variables are in parentheses. ${ }^{1}$ Acemoglou et al (2001), ${ }^{2}$ Hall and Jones (1999), ${ }^{3}$ Alesina et al (2003), ${ }^{4}$ Masters and McMillan (2001), ${ }^{5}$ Gallup and Sachs (1998), ${ }^{6}$ Sachs (2001), ${ }^{7}$ Sachs and Warner (1995), and Wacziarg and Welch (2003), ${ }^{8}$ Frankel and Romer (1999), ${ }^{9}$ Mcarthur and Sachs (2001), ${ }^{10}$ World Bank, ${ }^{11}$ IMF and World Bank ${ }^{12}$ Freedom House 
Table A3: List of countries in sample

\begin{tabular}{|c|c|c|c|}
\hline Country Code & OECD (22) & Country Code & Latin America (22) \\
\hline AUS & Australia & $\mathrm{BOL}$ & Bolivia@ \\
\hline JPN & Japan & COL & Colombia \\
\hline NZL & New Zealand & CRI & Costa Rica \\
\hline GRC & Greece & DOM & Dominican Republic $\odot$ \\
\hline PRT & Portugal & ECU & Ecuador \\
\hline CAN & Canada & GTM & Guatemala $\odot$ \\
\hline USA & United States & GUY & Guyana \\
\hline AUT & Austria & JAM & Jamaica@ \\
\hline BEL & Belgium & PER & Peru \\
\hline $\mathrm{CHE}$ & Switzerland & PRY & Paraguay@ \\
\hline DNK & Denmark & SLV & El Salvador@ \\
\hline ESP & Spain & HND & Honduras@ \\
\hline FIN & Finland & HTI & Haiti $\Delta$ \\
\hline FRA & France & NIC & Nicaragua $\odot$ \\
\hline GBR & United Kingdom & ARG & Argentina \\
\hline IRL & Ireland & BRA & Brazil \\
\hline ISL & Iceland & CHL & Chile \\
\hline ITA & Italy & MEX & Mexico \\
\hline LUX & Luxembourg & PAN & Panama \\
\hline NLD & Netherlands & TTO & Trinidad and Tobago $\odot$ \\
\hline NOR & Norway & URY & Uruguay \\
\hline SWE & Sweden & VEN & Venezuela \\
\hline Country Code & Sub-Sahara Africa (26) & Country Code & Asia and Pacific (13) \\
\hline AGO & Angola $\Delta$ & BGD & Bangladesh $\Delta$ \\
\hline BWA & Botswana & $\mathrm{CHN}$ & China \\
\hline CIV & Cote d'Ivoire & IDN & Indonesia \\
\hline CMR & Cameroon & IND & India \\
\hline ETH & Ethiopia $\Delta$ & KOR & Korea, Rep. \\
\hline GAB & Gabon & LKA & Sri Lanka \\
\hline GHA & Ghana & MYS & Malaysia \\
\hline GIN & Guinea $\Delta$ & PAK & Pakistan \\
\hline GNB & Guinea-Bissau $\Delta$ & SGP & Philippines \\
\hline KEN & Kenya & SGP & Singapore \\
\hline LBR & Liberia $\Delta$ & THA & Thailand \\
\hline MDG & Madagascar $\Delta$ & VNM & Vietnam \\
\hline MLI & $\operatorname{Mali} \Delta$ & PNG & Papua New Guinea $\odot$ \\
\hline $\mathrm{MOZ}$ & Mozambique $\Delta$ & & \\
\hline MWI & Malawi $\Delta$ & Country Code & Middle East and North Africa (13) \\
\hline NER & Niger $\Delta$ & ARE & United Arab Emirates \\
\hline NGA & Nigeria & ISR & Israel \\
\hline SDN & $\operatorname{Sudan} \Delta$ & KWT & Kuwait \\
\hline SEN & Senegal $\Delta$ & IRN & Iran, Islamic Rep. \\
\hline TGO & $\operatorname{Togo} \Delta$ & JOR & Jordan \\
\hline TZA & $\operatorname{Tanzania} \Delta$ & SYR & Syrian Arab Republic \\
\hline UGA & Uganda $\Delta$ & BHR & Bahrain \\
\hline ZAF & South Africa & $\mathrm{OMN}$ & Oman \\
\hline ZAR & Congo, Dem. Rep. $\Delta$ & SAU & Saudi Arabia \\
\hline ZMB & Zambia $\Delta$ & DZA & Algeria \\
\hline \multirow[t]{2}{*}{ ZWE } & Zimbabwe & EGY & Egypt, Arab Rep. \\
\hline & & MAR & Morocco \\
\hline Country Code & EU and Other Europe (6) & TUN & Tunisia \\
\hline ALB & Albania & & \\
\hline BGR & Bulgaria & & \\
\hline ROM & Romania & & \\
\hline HUN & Hungary & & \\
\hline POL & Poland & & \\
\hline TUR & Turkey & & \\
\hline
\end{tabular}

Source: United Nations and World Bank

$\Delta$ are LDCs and

(C) are SMEs in the sample of countries 
Table A4: Correlation of institution dimensions with development dimensions

\begin{tabular}{||lcccc||}
\hline & \multicolumn{3}{c||}{ Development Quality Index dimensions } \\
\hline & $\begin{array}{c}\text { Log of GDP per } \\
\text { capita(constant } \\
\text { 2000 US\$) }\end{array}$ & Economic DQ & Health DQ & Education DQ $\begin{array}{c}\text { Development } \\
\text { Quality Index }\end{array}$ \\
\hline \hline & $(1980-2004)$ & $(1980-2004)$ & $(1980-2004)$ & $(1980-2004)$ \\
\hline Institutional Quality Index (1980-2004) & 0.79 & 0.79 & 0.77 & 0.74 \\
Political IQ (1980-2004) & 0.68 & 0.66 & 0.63 & 0.68 \\
Social IQ (1980-2004) & 0.69 & 0.74 & 0.71 & 0.66 \\
Economic IQ (1980-2004) & 0.85 & 0.83 & 0.84 & 0.74 \\
\hline
\end{tabular}

Notes: All coefficients are significant at 1 percent.

Table A5: Correlation of Development Quality Index (DQI) with all other variables in the analysis

\begin{tabular}{|c|c|c|c|c|c|}
\hline Code & DQI 1980-2004 & Code & DQI 1980-2004 & Code & DQI 1980-2004 \\
\hline smajr & $\begin{array}{l}-0.69 * * * \\
\end{array}$ & frstarea & $0.70 * * *$ & SW & $0.42 * * *$ \\
\hline engfrac & $0.25 * * *$ & frstday & $0.74 * * *$ & epolc & $0.43 * * *$ \\
\hline eurfrac & $0.22 * *$ & tropical & $-0.577 * * *$ & yearsopen & $0.69 * * *$ \\
\hline geog & $0.74 * * *$ & access & -0.13 & $\operatorname{lninf}$ & $-0.41 * * *$ \\
\hline language & $-0.41 * * *$ & mal94p & $-0.65 * * *$ & ome & $0.34 * * *$ \\
\hline ethnic & $-0.60 * * *$ & malfal & $-0.60 * * *$ & $\mathrm{cmr}$ & $0.46 * * *$ \\
\hline religion & -0.03 & malfal94 & $-0.58 * * *$ & imfc & $0.26 * * *$ \\
\hline protestant & $0.45 * * *$ & meantemp & $-0.75 * * *$ & & \\
\hline catholoc & 0.031 & kgptemp & $0.74 * * *$ & & \\
\hline \multirow[t]{5}{*}{ muslim } & $-0.33 * * *$ & me & $-0.49 * * *$ & & \\
\hline & & $1 \mathrm{t} 100 \mathrm{~km}$ & $0.32 * * *$ & & \\
\hline & & lenerg & $0.22 * *$ & & \\
\hline & & elwardum & $-0.425 * * *$ & & \\
\hline & & state & $-0.42 * * *$ & & \\
\hline
\end{tabular}

Notes: Sample size varies with the choice of indicator. ***Significant at 1 percent, **Significant at 5 percent, $*$ Significant at 10 percent, Source: See Table A2 for acronyms 
Table A6: OLS Regressions: Determinants of DQI

\begin{tabular}{|c|c|c|c|c|c|c|}
\hline \multirow[b]{2}{*}{ Panel 1} & \multicolumn{6}{|c|}{ Dependent variable: Development Quality Index (DQI) } \\
\hline & 1980-1984 & 1985-1989 & 1990-1994 & $1995-1999$ & 2000-2004 & 1980-2004 \\
\hline IQI & $\begin{array}{c}\mathbf{1 . 2 9} * * * \\
(0.13)\end{array}$ & $\begin{array}{c}\mathbf{1 . 8 9} * * * * \\
(0.23)\end{array}$ & $\begin{array}{c}\mathbf{2 . 4 6} * * * * \\
(0.31)\end{array}$ & $\begin{array}{c}\mathbf{2 . 1 6} * * * * \\
(0.34)\end{array}$ & $\begin{array}{c}\mathbf{2 . 3 8} * * * \\
(0.33)\end{array}$ & $\begin{array}{c}2.25 * * * \\
(0.27)\end{array}$ \\
\hline Geography & $\begin{array}{c}3.51 * * * \\
(0.45)\end{array}$ & $\begin{array}{c}4.87 * * * \\
(0.71)\end{array}$ & $\begin{array}{c}4.53 * * * \\
(1.06))\end{array}$ & $\begin{array}{c}5.16^{* * * *} \\
(1.06)\end{array}$ & $\begin{array}{c}5.59 * * * \\
(1.29)\end{array}$ & $\begin{array}{c}4.29 * * * \\
(0.85)\end{array}$ \\
\hline Economic policy & $\begin{array}{l}0.24 * \\
(0.15) \\
\end{array}$ & $\begin{array}{l}0.52 * \\
(0.30) \\
\end{array}$ & $\begin{array}{l}0.59 * \\
(0.35) \\
\end{array}$ & $\begin{array}{l}0.65^{*} \\
(0.36) \\
\end{array}$ & $\begin{array}{l}0.71 * \\
(0.59) \\
\end{array}$ & $\begin{array}{l}0.64 * \\
(0.35) \\
\end{array}$ \\
\hline $\begin{array}{l}\text { R-squared } \\
\text { F-statistics }\end{array}$ & $\begin{array}{c}0.82 \\
151.81\end{array}$ & $\begin{array}{c}0.79 \\
164.8\end{array}$ & $\begin{array}{c}0.76 \\
146.06\end{array}$ & $\begin{array}{c}0.70 \\
102.11\end{array}$ & $\begin{array}{c}0.66 \\
107.1\end{array}$ & $\begin{array}{c}0.78 \\
160.54\end{array}$ \\
\hline Panel 2 & \multicolumn{6}{|c|}{ Dependent variable: Development Quality Index (DQI) } \\
\hline Political IQI & $\begin{array}{c}1.29 * * * \\
(0.15)\end{array}$ & $\begin{array}{c}\mathbf{1 . 7 7} * * * \\
(0.23)\end{array}$ & $\begin{array}{c}\mathbf{2 . 1 7} * * * \\
(0.32)\end{array}$ & $\begin{array}{c}\mathbf{1 . 4 3}^{* * * *} \\
(0.31)\end{array}$ & $\begin{array}{c}\mathbf{1 . 8 4} * * * \\
(0.38)\end{array}$ & $\begin{array}{c}2.16^{* * * *} \\
(0.30)\end{array}$ \\
\hline Geography & $\begin{array}{c}4.48 * * * \\
(0.44)\end{array}$ & $\begin{array}{c}6.32 * * * \\
(0.66)\end{array}$ & $\begin{array}{c}7.01 * * * \\
(0.99)\end{array}$ & $\begin{array}{c}7.36 * * * \\
(0.97)\end{array}$ & $\begin{array}{c}7.89 * * * \\
(1.20)\end{array}$ & $\begin{array}{c}6.05^{* * * *} \\
(0.82)\end{array}$ \\
\hline Economic policy & $\begin{array}{c}0.39 * * * \\
(0.16)\end{array}$ & $\begin{array}{c}0.82 * * * \\
(0.32)\end{array}$ & $\begin{array}{c}0.85^{* * *} \\
(0.41) \\
\end{array}$ & $\begin{array}{l}0.87 * * \\
(0.42) \\
\end{array}$ & $\begin{array}{l}0.99 * \\
(0.63) \\
\end{array}$ & $\begin{array}{c}0.96^{* * * *} \\
(0.39) \\
\end{array}$ \\
\hline R-squared & 0.79 & 0.74 & 0.68 & 0.62 & 0.59 & 0.73 \\
\hline F-statistics & 117.86 & 122.63 & 109.03 & 73.64 & 78.91 & 114.17 \\
\hline Panel 3 & \multicolumn{6}{|c|}{ "Dependent variable: Development Quality Index (DQI) } \\
\hline Social IQI & $\begin{array}{c}\mathbf{1 . 8 4} * * * \\
(0.23)\end{array}$ & $\begin{array}{c}\mathbf{2 . 5 2} * * * * \\
(0.35)\end{array}$ & $\begin{array}{c}\mathbf{2 . 7 7} * * * \\
(0.36)\end{array}$ & $\begin{array}{c}\mathbf{1 . 9 9} * * * \\
(0.32)\end{array}$ & $\begin{array}{c}\mathbf{2 . 7 5} * * * \\
(0.37)\end{array}$ & $\begin{array}{c}2.62 * * * \\
(0.34)\end{array}$ \\
\hline Geography & $\begin{array}{c}4.11 * * * \\
(0.41)\end{array}$ & $\begin{array}{c}5.54 * * * \\
(0.67)\end{array}$ & $\begin{array}{c}5.76 * * * \\
(0.93)\end{array}$ & $\begin{array}{c}6.39 * * * \\
(0.85)\end{array}$ & $\begin{array}{c}6.11^{* * * *} \\
(1.17)\end{array}$ & $\begin{array}{c}5.29 * * * \\
(0.75)\end{array}$ \\
\hline Economic policy & $\begin{array}{c}0.27 \\
(0.18) \\
\end{array}$ & $\begin{array}{c}0.53 \\
(0.36) \\
\end{array}$ & $\begin{array}{c}0.49 \\
(0.41) \\
\end{array}$ & $\begin{array}{c}0.58 \\
(0.43) \\
\end{array}$ & $\begin{array}{c}0.59 \\
(0.62) \\
\end{array}$ & $\begin{array}{c}0.59 \\
(0.43) \\
\end{array}$ \\
\hline $\begin{array}{l}\text { R-squared } \\
\text { F-statistics } \\
\end{array}$ & $\begin{array}{c}0.78 \\
153.22 \\
\end{array}$ & $\begin{array}{c}0.74 \\
171.63 \\
\end{array}$ & $\begin{array}{c}0.71 \\
166.69 \\
\end{array}$ & $\begin{array}{c}0.66 \\
121.97 \\
\end{array}$ & $\begin{array}{c}0.64 \\
124.36 \\
\end{array}$ & $\begin{array}{c}0.73 \\
185.62 \\
\end{array}$ \\
\hline Panel 4 & \multicolumn{6}{|c|}{ "Dependent variable: Development Quality Index (DQI) } \\
\hline Economic IQI & $\begin{array}{c}\mathbf{1 . 9 2} * * * \\
(0.23)\end{array}$ & $\begin{array}{c}\mathbf{2 . 9 5}^{* * *} \\
(0.43)\end{array}$ & $\begin{array}{c}\mathbf{4 . 2 8}^{* * * *} \\
(0.56)\end{array}$ & $\begin{array}{c}\mathbf{4 . 3 6}^{* * * *} \\
(0.64)\end{array}$ & $\begin{array}{c}\mathbf{5 . 7 7} * * * \\
(0.88)\end{array}$ & $\begin{array}{c}4.10^{* * * *} \\
(0.50)\end{array}$ \\
\hline Geography & $\begin{array}{c}3.08 * * * \\
(0.51)\end{array}$ & $\begin{array}{c}4.44 * * * \\
(0.80)\end{array}$ & $\begin{array}{c}3.50 * * * \\
(1.13)\end{array}$ & $\begin{array}{c}3.51 * * * \\
(1.16)\end{array}$ & $\begin{array}{l}2.78^{*} \\
(1.65)\end{array}$ & $\begin{array}{c}2.97 * * * * \\
(0.94)\end{array}$ \\
\hline Economic policy & $\begin{array}{c}0.15 \\
(0.13) \\
\end{array}$ & $\begin{array}{c}0.28 \\
(0.28) \\
\end{array}$ & $\begin{array}{c}0.36 \\
(0.30) \\
\end{array}$ & $\begin{array}{c}0.31 \\
(0.29) \\
\end{array}$ & $\begin{array}{c}0.25 \\
(0.45) \\
\end{array}$ & $\begin{array}{c}0.32 \\
(0.28) \\
\end{array}$ \\
\hline $\begin{array}{l}\text { R-squared } \\
\text { F-statistics }\end{array}$ & $\begin{array}{c}0.81 \\
142.14 \\
\end{array}$ & $\begin{array}{c}0.79 \\
166.31 \\
\end{array}$ & $\begin{array}{c}0.79 \\
146.77 \\
\end{array}$ & $\begin{array}{c}0.76 \\
108.92 \\
\end{array}$ & $\begin{array}{c}0.74 \\
122.63 \\
\end{array}$ & $\begin{array}{c}0.82 \\
171.1 \\
\end{array}$ \\
\hline $\begin{array}{l}\text { Observations } \\
\text { \# Countries }\end{array}$ & $\begin{array}{l}102 \\
102\end{array}$ & $\begin{array}{l}102 \\
102\end{array}$ & $\begin{array}{l}102 \\
102\end{array}$ & $\begin{array}{l}102 \\
102\end{array}$ & $\begin{array}{l}102 \\
102\end{array}$ & $\begin{array}{l}102 \\
102\end{array}$ \\
\hline
\end{tabular}

Notes: Constants are not reported. Robust standard errors adjusted for clustering by country in parentheses t-statistics, ***Significant at 1 percent, $* *$ Significant at 5 percent, $*$ Significant at 10 percent 
Table A7: 2SLS-IV Regression estimates of DQI with Acemoglu, Johnson and Robinson (2001) Instruments for IQI

\begin{tabular}{|c|c|c|c|c|c|c|c|c|}
\hline \multirow[t]{2}{*}{ Panel A: Second-stage regressions } & \multicolumn{8}{|c|}{$\begin{array}{l}\text { Dependent variable: Development Quality Index } \\
\text { Ex-colony sample }\end{array}$} \\
\hline & \multicolumn{2}{|c|}{ All } & \multicolumn{2}{|c|}{ Excluding neo-Europes } & \multicolumn{2}{|c|}{ Excluding Africa } & \multicolumn{2}{|c|}{$\begin{array}{c}\text { Excluding neo-Europe } \\
\text { and Africa } \\
\end{array}$} \\
\hline Institutional Quality Index(IQI) & $\begin{array}{c}3.57 * * * \\
(0.58)\end{array}$ & & $\begin{array}{c}3.54 * * * \\
(0.85)\end{array}$ & & $\begin{array}{c}3.20 * * * \\
(0.84)\end{array}$ & & $\begin{array}{c}3.27 * * * \\
(1.33)\end{array}$ & \\
\hline Economic policy (EPOL) & $\begin{array}{l}1.30 \\
(0.86)\end{array}$ & & $\begin{array}{l}1.42 * \\
(0.85)\end{array}$ & & $\begin{array}{c}2.34 * * * \\
(0.88)\end{array}$ & & $\begin{array}{c}2.24 * * \\
(0.97)\end{array}$ & \\
\hline Geography(GEOG) & $\begin{array}{l}0.06 \\
(7.92)\end{array}$ & & $\begin{array}{l}10.94 \\
(9.64)\end{array}$ & & $\begin{array}{l}23.28^{*} \\
(11.36)\end{array}$ & & $\begin{array}{l}29.88^{* *} \\
(11.36)\end{array}$ & \\
\hline Observations & 59 & & 60 & & 40 & & 36 & \\
\hline R-squared & 0.47 & & 0.31 & & 0.46 & & 0.32 & \\
\hline Instruments & \multicolumn{8}{|c|}{ Settler Mortality and constructed trade share } \\
\hline Heteroskedasticity test: (p-value) & & 0.01 & 0.08 & & 0.81 & & 0.41 & \\
\hline Over-identification test: ( $\mathrm{p}$-value) & \multicolumn{8}{|c|}{ Exactly identified equations } \\
\hline Endogeneity test: (p-value) & & 0.01 & 0.00 & & 0.01 & & 0.00 & \\
\hline \multicolumn{9}{|l|}{ Panel B: First-stage regressions } \\
\hline & \multicolumn{8}{|c|}{ Dependent variables } \\
\hline & $\begin{array}{c}\text { IQI } \\
(1980-2000)\end{array}$ & $\begin{array}{c}\text { EPOL } \\
(1980-2000)\end{array}$ & $\begin{array}{c}\text { IQI } \\
(1980-2000)\end{array}$ & $\begin{array}{l}\text { EPOL } \\
(1980- \\
2000)\end{array}$ & $\begin{array}{c}\text { IQI } \\
(1980- \\
2000)\end{array}$ & $\begin{array}{c}\text { EPOL } \\
(1980- \\
2000)\end{array}$ & $\begin{array}{c}\text { IQI } \\
(1980- \\
2000)\end{array}$ & $\begin{array}{l}\text { EPOL } \\
(1980- \\
2000)\end{array}$ \\
\hline Geography & $\begin{array}{l}4.09^{*} \\
(2.16)\end{array}$ & $\begin{array}{l}-3.70 \\
(2.65)\end{array}$ & $\begin{array}{c}1.42 \\
(1.87)\end{array}$ & $\begin{array}{c}-5.74 * * * \\
(2.45)\end{array}$ & $\begin{array}{c}1.38 \\
(2.20)\end{array}$ & $\begin{array}{c}-6.69^{* *} \\
(3.11)\end{array}$ & $\begin{array}{l}-0.27 \\
(2.20)\end{array}$ & $\begin{array}{c}-9.65 * * * \\
(3.31)\end{array}$ \\
\hline Settler mortality $(\log )$ & $\begin{array}{c}-1.04 * * * \\
(0.24)\end{array}$ & $\begin{array}{l}-0.04 \\
(0.29)\end{array}$ & $\begin{array}{c}-0.78 * * * \\
(0.21)\end{array}$ & $\begin{array}{c}0.04 \\
(0.28)\end{array}$ & $\begin{array}{c}1.42^{* * * *} \\
(0.33)\end{array}$ & $\begin{array}{l}-0.50 \\
(0.47)\end{array}$ & $\begin{array}{c}-1.06 * * * \\
(0.34)\end{array}$ & $\begin{array}{l}-0.43 \\
(0.51)\end{array}$ \\
\hline Constructed trade share(EPOLC) & $\begin{array}{l}-0.34 \\
(0.40)\end{array}$ & $\begin{array}{c}1.85^{* * *} \\
(0.49)\end{array}$ & $\begin{array}{c}0.30 \\
(0.37)\end{array}$ & $\begin{array}{c}2.06^{* * *} \\
(0.48)\end{array}$ & $\begin{array}{l}-0.74 * \\
(0.42)\end{array}$ & $\begin{array}{c}1.84 * * * \\
(0.60)\end{array}$ & $\begin{array}{l}-0.16^{*} \\
(0.44)\end{array}$ & $\begin{array}{c}2.02 * * * \\
(0.65)\end{array}$ \\
\hline F-Test for excluded instruments & 9.59 & 7.58 & 9.06 & 9.99 & 9.99 & 5.91 & 4.85 & 6.67 \\
\hline R-squared & 0.42 & 0.27 & 0.32 & 0.31 & 0.50 & 0.35 & 0.26 & 0.41 \\
\hline Shea R-squared & 0.27 & 0.22 & 0.20 & 0.22 & 0.36 & 0.25 & 0.20 & 0.25 \\
\hline
\end{tabular}

Note: Constants are not reported. T-statistics in the first-stage regressions, and Z-statistics in second stage regressions. Robust standard errors adjusted for clustering by country in parentheses $* * *$ Significant at 1 percent, $* *$ Significant at 5 percent, $*$ Significant at 10 percent. 
Table A8: 2SLS-IV Regression estimates of DQI with Hall and Jones (1999) Instruments for IQI

\begin{tabular}{|c|c|c|c|c|}
\hline \multirow[t]{2}{*}{ Second-stage regressions } & \multicolumn{4}{|c|}{ Dependent variable: Development Quality Index } \\
\hline & Col.5 & Col.6 & Col.7 & Col.8 \\
\hline Institutional Quality Index(IQI) & $\begin{array}{c}\mathbf{1 . 6 9} * * * \\
(-0.37)\end{array}$ & & & \\
\hline Political Institutional Quality Index(IQI) & & $\begin{array}{c}1.84 * * * * \\
(0.44)\end{array}$ & & \\
\hline Social Institutional Quality Index(IQI) & & & $\begin{array}{c}2.38 * * * * \\
(0.61)\end{array}$ & \\
\hline Economic Institutional Quality Index(IQI) & & & & $\begin{array}{c}3.87 * * * \\
(0.68)\end{array}$ \\
\hline Economic policy (EPOL) & $\begin{array}{c}1.27 * * * * \\
(-0.54)\end{array}$ & $\begin{array}{c}1.50 * * * \\
(0.59)\end{array}$ & $\begin{array}{l}1.25^{* *} \\
(0.61)\end{array}$ & $\begin{array}{c}0.85^{* *} \\
(0.38)\end{array}$ \\
\hline Geography(GEOG) & $\begin{array}{c}5.53 * * * \\
(-1.03)\end{array}$ & $\begin{array}{c}32.80 * * * * \\
(4.76)\end{array}$ & $\begin{array}{c}28.74 * * * \\
(5.32)\end{array}$ & $\begin{array}{c}17.01 * * * \\
(5.89)\end{array}$ \\
\hline Observations & 99 & 99 & 99 & 99 \\
\hline R-squared & 0.76 & 0.72 & 0.71 & 0.82 \\
\hline Instruments & \multicolumn{4}{|c|}{ engfrac, eurfrac, epolc } \\
\hline $\begin{array}{l}\text { Heteroskedasticity test: Breusch-Pagan/Godfrey/Cook-Weisberg } \chi^{2} \text { (p-value) } \\
\text { Over-identification test: Hansen-Sargan J statistic } \chi^{2} \text { (p-value) }\end{array}$ & $\begin{array}{l}0.000 \\
0.833\end{array}$ & $\begin{array}{l}0.00 \\
0.90\end{array}$ & $\begin{array}{l}0.00 \\
0.75\end{array}$ & $\begin{array}{c}0.010 \\
0.44\end{array}$ \\
\hline Endogeneity test: Durbin-Wu-Hausman: $\chi^{2}$ (p-value) & 0.024 & 0.17 & 0.14 & 0.19 \\
\hline F-Test for excluded instruments: IQI dimensions & 19.41 & 22.12 & 17.45 & 8.59 \\
\hline OPEN 1980-2004 & 18.50 & 18.50 & 18.50 & 18.50 \\
\hline Shea R-squared: IQI dimensions & 0.38 & 0.41 & 0.36 & 0.19 \\
\hline OPEN 1980-2004 & 0.37 & 0.37 & 0.37 & 0.34 \\
\hline
\end{tabular}

Note: Constants are not reported. Z-statistics. Robust standard errors adjusted for clustering by country in parentheses ***Significant at 1 percent,

**Significant at 5 percent, * Significant at 10 percent. First-stage results are not reported. 
Table A9: Robustness checks 2SLS-IV Regression estimates: Region, Legal origin, Religion, Language and Ethnic fractionalization

\begin{tabular}{|c|c|c|c|c|c|c|c|c|c|c|}
\hline \multirow[t]{2}{*}{ Second-stage regressions } & \multicolumn{10}{|c|}{ Dependent variable: Development Quality Index } \\
\hline & Col.1 & Col.2 & Col.3 & Col.4 & Col.5 & Col.6 & Col.7 & Col.8 & Col.9 & Col.10 \\
\hline Institutional Quality Index(IQI) & $4.55^{* * *}$ & $3.49^{* * *}$ & $3.61 * * *$ & $4.21 * *$ & $3.58^{* * *}$ & $2.16^{* * *}$ & $1.89^{* * *}$ & $1.81 * * *$ & $1.85^{* * *}$ & $1.80 * * *$ \\
\hline & $(1.59)$ & $(0.84)$ & $(0.64)$ & $(0.87)$ & $(0.63)$ & $(0.32)$ & $(0.26)$ & $(0.28)$ & $(0.31)$ & $(0.28)$ \\
\hline Economic policy (EPOL) & $\begin{array}{c}1.32 \\
(0.92)\end{array}$ & $\begin{array}{c}1.36 \\
(0.85)\end{array}$ & $\begin{array}{c}1.27 \\
(0.83)\end{array}$ & $\begin{array}{l}1.71 * * \\
(0.81)\end{array}$ & $\begin{array}{c}1.32 \\
(0.90)\end{array}$ & $\begin{array}{l}0.43^{*} \\
(0.26)\end{array}$ & $\begin{array}{c}0.65^{* * *} \\
(0.27)\end{array}$ & $\begin{array}{c}0.72 * * * \\
(0.26)\end{array}$ & $\begin{array}{c}0.75 * * * \\
(0.26)\end{array}$ & $\begin{array}{c}0.71 * * * \\
(0.25)\end{array}$ \\
\hline Geography(GEOG) & $\begin{array}{c}8.95 \\
(13.22)\end{array}$ & $\begin{array}{l}10.91 \\
(9.44)\end{array}$ & $\begin{array}{l}-0.70 \\
(8.14)\end{array}$ & $\begin{array}{c}2.59 \\
(9.05)\end{array}$ & $\begin{array}{c}0.32 \\
(8.31)\end{array}$ & $\begin{array}{c}17.08 * * * \\
(6.71)\end{array}$ & $\begin{array}{c}25.82 * * * \\
(3.69)\end{array}$ & $\begin{array}{c}28.20 * * * \\
(4.15)\end{array}$ & $\begin{array}{c}27.12 * * * \\
(3.85)\end{array}$ & $\begin{array}{c}25.93 * * * \\
(4.03)\end{array}$ \\
\hline Asia Dummy & $\begin{array}{c}2.19 \\
(3.43)\end{array}$ & & & & & $\begin{array}{l}-2.04 \\
(2.08)\end{array}$ & & & & \\
\hline Sub-Saharan Africa Dummy & $\begin{array}{c}3.11 \\
(5.51)\end{array}$ & & & & & $\begin{array}{l}-3.43^{*} \\
(1.89)\end{array}$ & & & & \\
\hline Latin America Dummy & $\begin{array}{l}-3.85 \\
(4.11)\end{array}$ & & & & & $\begin{array}{c}-4.12 * * \\
(1.84)\end{array}$ & & & & \\
\hline French legal origin & & $\begin{array}{l}-0.82 \\
(1.81)\end{array}$ & & & & & $\begin{array}{l}-1.28 \\
(0.90)\end{array}$ & & & \\
\hline Religion fractionalization & & & $\begin{array}{l}-1.04 \\
(3.09)\end{array}$ & & & & & $\begin{array}{c}2.89 \\
(1.95)\end{array}$ & & \\
\hline Language fractionalization & & & & $\begin{array}{l}7.81^{*} \\
(4.39)\end{array}$ & & & & & $\begin{array}{c}0.22 \\
(1.56)\end{array}$ & \\
\hline Ethnic fractionalization & & & & & $\begin{array}{c}0.31 \\
(3.83)\end{array}$ & & & & & $\begin{array}{l}-1.81 \\
(2.03)\end{array}$ \\
\hline p-values for regional dummy & 0.30 & & & & & 0.11 & & & & \\
\hline Instruments & & & mortality, & & & & & c, eurfrac, & & \\
\hline Outlier countries & & Zurope (Austr & Canada, $\mathrm{Ne}$ & aland, and & & & & an and Singar & & \\
\hline Observations & 60 & 60 & 60 & 60 & 259 & 97 & 97 & 97 & 95 & 97 \\
\hline R-squared & 0.70 & 0.76 & 0.79 & 0.74 & 0.79 & 0.87 & 0.87 & 0.86 & 0.86 & 0.86 \\
\hline
\end{tabular}

Constants are not reported. Robust standard errors adjusted for clustering by country in parentheses. Z-statistics. ***Significant at 1 percent, **Significant at 5 percent, * Significant at 10 percent. Hadi procedure to detect outliers in sample. First stage results not reported to save space. 
Table A10: Robustness checks 2SLS-IV Regression estimates: Additional geography measures

\begin{tabular}{|c|c|c|c|c|c|c|c|c|}
\hline \multirow[t]{2}{*}{ Second-stage regressions } & \multicolumn{8}{|c|}{ Dependent variable: Development Quality Index } \\
\hline & Col.1 & Col.2 & Col.3 & Col.4 & Col.5 & Col.6 & Col.7 & Col.8 \\
\hline Institutional Quality Index(IQI) & $1.82^{* * *}$ & $1.85^{* * *}$ & $1.95^{* * *}$ & $1.94 * * *$ & $1.76^{* * *}$ & $1.79 * * *$ & $1.84 * * *$ & $1.87 * * *$ \\
\hline Economic policy (EPOL) & $\begin{array}{c}0.69 * * * \\
(0.25)\end{array}$ & $\begin{array}{c}0.74 * * * \\
(0.25)\end{array}$ & $\begin{array}{l}0.55^{*} \\
(0.29)\end{array}$ & $\begin{array}{c}0.81 * * * \\
(0.33)\end{array}$ & $\begin{array}{c}0.85 * * * \\
(0.27)\end{array}$ & $\begin{array}{c}0.76^{* * * *} \\
(0.26)\end{array}$ & $\begin{array}{c}0.50 \\
(0.48)\end{array}$ & $\begin{array}{c}0.78 \\
(0.29) * * *\end{array}$ \\
\hline Geography(GEOG) & $\begin{array}{c}27.21 * * * \\
(3.85)\end{array}$ & $\begin{array}{c}26.37 * * * * \\
(6.25)\end{array}$ & $\begin{array}{c}24.87 * * * \\
(6.60)\end{array}$ & $\begin{array}{c}14.74 * * * * \\
(4.86)\end{array}$ & $\begin{array}{c}21.46 * * * * \\
(4.52)\end{array}$ & $\begin{array}{c}24.77 * * * \\
(5.25)\end{array}$ & $\begin{array}{c}26.08 * * * \\
(4.80)\end{array}$ & $\begin{array}{c}24.89 * * * \\
(4.37)\end{array}$ \\
\hline$\%$ of tropical land area & & $\begin{array}{l}-0.30 \\
(1.75)\end{array}$ & & & & & & \\
\hline$\%$ Area under frost in winter & & & $\begin{array}{c}1.63 \\
(2.43)\end{array}$ & & & & & \\
\hline Days under frost in winter & & & & $\begin{array}{c}0.32 * * * \\
(0.10)\end{array}$ & & & & \\
\hline$\%$ land area within $100 \mathrm{~km}$ of sea & & & & & & & $\begin{array}{c}1.50 \\
(2.36)\end{array}$ & \\
\hline Hydrocarbon production per capita & & & & & & & & $\begin{array}{c}0.37 * * \\
(0.17) \\
\end{array}$ \\
\hline Instruments & & & & engfrac, & frac, epolc & & & \\
\hline Outlier countries & & & & Japan ar & Singapore & & & \\
\hline Observations & 97 & 97 & 76 & 76 & 97 & 97 & 94 & 92 \\
\hline R-squared & 0.86 & 0.86 & 0.89 & 0.90 & 0.86 & 0.86 & 0.86 & 0.86 \\
\hline
\end{tabular}

Note: Constants are not reported. Robust standard errors adjusted for clustering by country in parentheses. Z-statistics. ***Significant at 1 percent,

**Significant at 5 percent, * Significant at 10 percent . Hadi procedure to detect outliers in sample. First stage results not reported to save space. 
Table A11: 2SLS-IV Regression estimates: DQI, Settler mortality, geography-Malaria burden

\begin{tabular}{|c|c|c|c|c|c|c|c|c|}
\hline \multirow[t]{2}{*}{ Second-stage regressions } & \multicolumn{8}{|c|}{ Dependent variable: Development Quality Index } \\
\hline & Col.1 & Col.2 & Col.3 & Col.4 & Col.5 & Col.6 & Col.7 & Col.8 \\
\hline Institutional Quality Index(IQI) & $\begin{array}{c}2.57 * * * \\
(0.66)\end{array}$ & & & & $\begin{array}{c}2.94 * * * \\
(0.38)\end{array}$ & & & \\
\hline Political IQI & & $\begin{array}{c}2.86 \\
(1.86)\end{array}$ & & & & $\begin{array}{c}4.31 * * * \\
(0.94)\end{array}$ & & \\
\hline Social IQI & & & $\begin{array}{c}1.25 \\
(1.29)\end{array}$ & & & & $\begin{array}{c}3.08^{* * * *} \\
(0.91)\end{array}$ & \\
\hline Economic IQI & & & & $\begin{array}{c}3.68 * * * \\
(0.68)\end{array}$ & & & & $\begin{array}{c}4.10 * * * \\
(0.46)\end{array}$ \\
\hline Economic policy (EPOL) & $\begin{array}{c}0.70 \\
(0.65) \\
\end{array}$ & $\begin{array}{c}1.19 * * \\
(0.68) \\
\end{array}$ & $\begin{array}{c}0.69 \\
(0.73) \\
\end{array}$ & $\begin{array}{c}0.43 \\
(0.46) \\
\end{array}$ & $\begin{array}{r}0.68 \\
(0.66) \\
\end{array}$ & $\begin{array}{l}1.38^{*} \\
(0.80) \\
\end{array}$ & $\begin{array}{c}0.46 \\
(0.81) \\
\end{array}$ & $\begin{array}{c}0.37 \\
(0.46) \\
\end{array}$ \\
\hline$\%$ of population live with risk of malaria transmission risk in 1994 & $\begin{array}{l}-3.85 \\
(4.14)\end{array}$ & $\begin{array}{l}-5.33 \\
(8.79)\end{array}$ & $\begin{array}{c}-14.29 * * * \\
(4.57)\end{array}$ & $\begin{array}{c}-5.49^{* *} \\
(2.68)\end{array}$ & & & & \\
\hline \% of population at risk of falciparum malaria transmission in 1994 & & & & & $\begin{array}{l}-1.49 \\
(2.25)\end{array}$ & $\begin{array}{c}1.81 \\
(4.12)\end{array}$ & $\begin{array}{c}-6.64^{* * *} \\
(3.05)\end{array}$ & $\begin{array}{c}-3.89 * * * \\
(1.63)\end{array}$ \\
\hline Observations & 57 & 57 & 57 & 57 & 57 & 57 & 57 & 57 \\
\hline R-squared & 0.71 & 2.86 & 0.48 & 0.77 & 0.71 & 0.48 & 0.60 & 0.78 \\
\hline Instruments & smajr, epol & meantemp lt & $0 \mathrm{~km}$ geog lener & tate elwardu & (for all Col & & & \\
\hline Heteroskedasticity test: Breusch-Pagan/Godfrey/Cook-Weisberg $\chi^{2}$ (p-value) & 0.00 & 0.00 & 0.51 & 0.05 & 0.00 & 0.00 & 0.00 & 0.00 \\
\hline Over-identification test: Hansen-Sargan J statistic $\chi^{2}$ (p-value) & 0.10 & 0.06 & 0.10 & 0.79 & 0.07 & 0.05 & 0.10 & 0.82 \\
\hline $\begin{array}{l}\text { Endogeneity test: Durbin-Wu-Hausman: } \chi^{2}(p-\text { value }) \\
\text { F-Test for excluded instruments: }\end{array}$ & 0.12 & 0.01 & 0.02 & 0.10 & 0.05 & 0.00 & 0.12 & 0.07 \\
\hline IQI dimensions & 13.85 & 8.82 & 12.15 & 14.80 & 13.85 & 8.82 & 12.15 & 14.80 \\
\hline EPOL 1980-2004 & 6.19 & 6.19 & 6.19 & 6.19 & 6.19 & 6.19 & 6.19 & 6.19 \\
\hline MAL94P/ MALFAL & 9.03 & 9.03 & 9.03 & 9.03 & 15.30 & 15.30 & 15.30 & 15.30 \\
\hline IQI dimensions & 0.17 & 0.07 & 0.23 & 0.30 & 0.42 & 0.27 & 0.41 & 0.50 \\
\hline EPOL 1980-2004 & 0.50 & 0.41 & 0.47 & 0.49 & 0.51 & 0.49 & 0.49 & 0.50 \\
\hline MAL94P/MALFAL & 0.15 & 0.07 & 0.21 & 0.26 & 0.44 & 0.33 & 0.45 & 0.51 \\
\hline
\end{tabular}

Note: Ex-colonies are included in the sample only. Constants are not reported. Robust standard errors adjusted for clustering by country in parentheses. Z-statistics.

***Significant at 1 percent, ${ }^{* *}$ Significant at 5 percent, $*$ Significant at 10 percent 
Table A12: 2SLS-IV Regression estimates: DQI, geography -Malaria burden

\begin{tabular}{|c|c|c|c|c|c|c|c|c|}
\hline \multirow[t]{2}{*}{ Second-stage regressions } & \multicolumn{8}{|c|}{ Dependent variable: Development Quality Index } \\
\hline & Col.1 & Col.2 & Col.3 & Col.4 & Col.5 & Col.6 & Col.7 & Col.8 \\
\hline Institutional Quality Index(IQI) & $\begin{array}{c}2.91 * * * \\
(0.71)\end{array}$ & & & & $\begin{array}{c}3.40 * * * \\
0.51\end{array}$ & & & \\
\hline Political IQI & & $\begin{array}{l}3.00 * * \\
(1.38)\end{array}$ & & & & $\begin{array}{c}4.77 * * * \\
1.16\end{array}$ & & \\
\hline Social IQI & & & $\begin{array}{c}3.51 * * * \\
(1.03)\end{array}$ & & & & $\begin{array}{c}4.52 * * * \\
0.79\end{array}$ & \\
\hline Economic IQI & & & & $\begin{array}{c}4.39 * * * \\
(0.75)\end{array}$ & & & & $\begin{array}{c}4.89 * * * \\
0.54\end{array}$ \\
\hline$\%$ of population live with risk of malaria transmission risk in 1994(mal94p) & $\begin{array}{l}-6.41 \\
(4.45)\end{array}$ & $\begin{array}{c}-11.31 * * * \\
\quad(6.20)\end{array}$ & $\begin{array}{c}-10.20 * * * \\
(4.08)\end{array}$ & $\begin{array}{c}-6.95^{* *} \\
(3.15)\end{array}$ & & & & \\
\hline$\%$ of population at risk of falciparum malaria transmission in 1994(malfal) & & & & & $\begin{array}{r}-3.05 \\
3.16\end{array}$ & $\begin{array}{c}-2.16 \\
5.34\end{array}$ & $\begin{array}{c}-5.46^{*} \\
3.23\end{array}$ & $\begin{array}{c}-5.06^{* *} \\
2.18\end{array}$ \\
\hline Economic policy (EPOL) & $\begin{array}{c}0.83 \\
(0.55) \\
\end{array}$ & $\begin{array}{c}1.26 * * \\
(0.62) \\
\end{array}$ & $\begin{array}{c}0.81 \\
(0.60) \\
\end{array}$ & $\begin{array}{c}0.47 \\
(0.39) \\
\end{array}$ & $\begin{array}{l}0.79 \\
0.58 \\
\end{array}$ & $\begin{array}{c}1.38^{* * * *} \\
0.75 \\
\end{array}$ & $\begin{array}{l}0.74 \\
0.68 \\
\end{array}$ & $\begin{array}{l}0.39 \\
0.39 \\
\end{array}$ \\
\hline Observations & 91 & 91 & 91 & 91 & 91 & 91 & 91 & 91 \\
\hline R-squared & 0.74 & 0.59 & 0.70 & 0.79 & 0.73 & 0.50 & 0.68 & 0.80 \\
\hline Instruments & epolc, mea & $\mathrm{mp}$ lt100km g & lenerg state el & $\operatorname{ardum}$ (for a & Cols.) & & & \\
\hline Heteroskedasticity test: Breusch-Pagan/Godfrey/Cook-Weisberg $\chi^{2}$ (p-value) & 0.00 & 0.00 & 0.00 & 0.02 & 0.00 & 0.00 & 0.00 & 0.05 \\
\hline Over-identification test: Hansen-Sargan J statistic $\chi^{2}$ (p-value) & 0.04 & 0.02 & 0.02 & 0.18 & 0.04 & 0.02 & 0.02 & 0.19 \\
\hline $\begin{array}{l}\text { Endogeneity test: Durbin-Wu-Hausman: } \chi^{2} \text { (p-value) } \\
\text { F-Test for excluded instruments: }\end{array}$ & 0.01 & 0.01 & 0.02 & 0.01 & 0.00 & 0.00 & 0.01 & 0.00 \\
\hline IQI dimensions & 27.83 & 13.62 & 29.24 & 30.20 & 27.83 & 13.62 & 29.24 & 30.20 \\
\hline EPOL 1980-2004 & 8.82 & 8.82 & 8.82 & 8.82 & 8.82 & 8.82 & 8.82 & 8.82 \\
\hline MAL94P/ MALFAL & 17.38 & 17.38 & 17.38 & 17.38 & 20.07 & 20.07 & 20.07 & 20.07 \\
\hline IQI dimensions & 0.19 & 0.12 & 0.21 & 0.26 & 0.38 & 0.23 & 0.36 & 0.45 \\
\hline EPOL 1980-2004 & 0.40 & 0.41 & 0.40 & 0.38 & 0.40 & 0.42 & 0.41 & 0.39 \\
\hline MAL94P/ MALFAL & 0.17 & 0.13 & 0.17 & 0.22 & 0.35 & 0.27 & 0.32 & 0.41 \\
\hline
\end{tabular}

Note: Constants are not reported. Robust standard errors adjusted for clustering by country in parentheses. Z-statistics. ***Significant at 1 percent, **Significant at 5

percent, * Significant at 10 percent. 
Table A13: Robustness checks: DQI in developing world, geography -Malaria burden

\begin{tabular}{|c|c|c|c|c|c|c|c|c|c|c|}
\hline \multirow[t]{3}{*}{ Second-stage regressions } & \multicolumn{10}{|c|}{ Dependent variable: Development Quality Index } \\
\hline & \multicolumn{8}{|c|}{ Developing country } & \multicolumn{2}{|c|}{ LDCs and SMEs } \\
\hline & Col.1 & Col.2 & Col.3 & Col.4 & Col.5 & Col.6 & Col.7 & Col.8 & Col.9 & Col.10 \\
\hline Institutional Quality Index(IQI) & $\begin{array}{l}0.93 * * \\
(0.48)\end{array}$ & & & & $\begin{array}{c}1.27 * * * \\
(0.49)\end{array}$ & & & & $\begin{array}{c}0.70^{* * * *} \\
(0.39)\end{array}$ & $\begin{array}{l}0.85^{*} \\
(0.34)\end{array}$ \\
\hline Political IQI & & $\begin{array}{c}0.43 \\
(0.67)\end{array}$ & & & & $\begin{array}{c}0.49 \\
(0.72)\end{array}$ & & & & \\
\hline Social IQI & & & $\begin{array}{l}0.69^{*} \\
(0.44)\end{array}$ & & & & $\begin{array}{c}0.93 * * \\
(0.40)\end{array}$ & & & \\
\hline Economic IQI & & & & $\begin{array}{c}1.69 * * \\
(0.78)\end{array}$ & & & & $\begin{array}{c}2.27 * * * \\
(0.69)\end{array}$ & & \\
\hline mal94p & $\begin{array}{c}-6.62 * * * \\
(1.77)\end{array}$ & $\begin{array}{c}-8.09 * * * \\
(2.19)\end{array}$ & $\begin{array}{c}-8.04 * * * \\
(1.30)\end{array}$ & $\begin{array}{c}-6.21 * * * \\
(1.53)\end{array}$ & & & & & $\begin{array}{c}-3.55 * * * \\
(1.59)\end{array}$ & \\
\hline malfal & & & & & $\begin{array}{c}-5.25 * * * \\
(1.50)\end{array}$ & $\begin{array}{c}-7.17 * * * \\
(2.16)\end{array}$ & $\begin{array}{c}-7.01 * * * \\
(1.09)\end{array}$ & $\begin{array}{c}-5.22 * * * \\
(1.21)\end{array}$ & & $\begin{array}{c}-2.59 * * \\
(0.90)\end{array}$ \\
\hline Instruments & & & epo & meantem & $\mathrm{t} 100 \mathrm{~km} \mathrm{ge}$ & g lenerg sta & elwardum & for all Cols & & \\
\hline Outlier countries & & & & Soutl & Korea & & & & & \\
\hline Observations & 69 & 69 & 69 & 69 & 69 & 69 & 69 & 69 & 29 & 29 \\
\hline R-squared & 0.56 & 0.48 & 0.53 & 0.57 & 0.56 & 0.59 & 0.57 & 0.57 & 0.67 & 0.71 \\
\hline
\end{tabular}

Note: Constants are not reported. Robust standard errors adjusted for clustering by country in parentheses. Z-statistics. ${ }^{* * *}$ Significant at 1 percent, $* *$ Significant at 5 percent, * Significant at 10 percent 
Table A14: 2SLS-IV Regression estimates: DQI with 'other' economic policy measures

\begin{tabular}{|c|c|c|c|c|c|c|c|c|c|c|}
\hline \multirow{3}{*}{$\begin{array}{l}\text { Second-stage regressions } \\
\text { Institutional Quality Index(IQI) }\end{array}$} & \multicolumn{10}{|c|}{ Dependent variable: Development Quality Index(DQI) } \\
\hline & \multicolumn{5}{|c|}{ Exogenous economic policy } & \multicolumn{5}{|c|}{ Endogenous economic policy } \\
\hline & $\begin{array}{c}2.86^{* * * *} \\
(0.40)\end{array}$ & $\begin{array}{c}2.43 * * * * \\
(0.40)\end{array}$ & $\begin{array}{c}2.75^{* * * *} \\
(0.52)\end{array}$ & $\begin{array}{c}2.85^{* * * *} \\
(0.45)\end{array}$ & $\begin{array}{c}3.12 * * * \\
(0.50)\end{array}$ & $\begin{array}{c}2.34 * * * \\
(0.51)\end{array}$ & $\begin{array}{c}2.12 * * * * \\
(0.52)\end{array}$ & $\begin{array}{l}1.84 * * \\
(0.96)\end{array}$ & $\begin{array}{c}2.68 * * * \\
(0.56)\end{array}$ & $\begin{array}{c}2.62 * * * \\
(0.53)\end{array}$ \\
\hline Inflation & $\begin{array}{l}-2.17 * \\
(1.27)\end{array}$ & & & & & $\begin{array}{l}-1.05 \\
(1.87)\end{array}$ & & & & \\
\hline Sachs-Warner-\# of years open & & $\begin{array}{c}9.26 * * \\
(4.69)\end{array}$ & & & & & $\begin{array}{l}11.87^{*} \\
(7.24)\end{array}$ & & & \\
\hline Exchange rate differential (Official vs. BMP) & & & $\begin{array}{c}0.47 \\
(0.41)\end{array}$ & & & & & $\begin{array}{c}1.42 \\
(1.26)\end{array}$ & & \\
\hline Credit market de-regulation & & & & $\begin{array}{c}0.92 \\
(0.80)\end{array}$ & & & & & $\begin{array}{c}0.46 \\
(1.15)\end{array}$ & \\
\hline Capital liberalization measures & & & & & $\begin{array}{c}0.35 \\
(1.98)\end{array}$ & & & & & $\begin{array}{c}-3.95 \\
(11.64)\end{array}$ \\
\hline malfal & $\begin{array}{l}-2.09 \\
(2.26) \\
\end{array}$ & $\begin{array}{l}-0.26 \\
(2.08) \\
\end{array}$ & $\begin{array}{l}-2.30 \\
(2.61) \\
\end{array}$ & $\begin{array}{l}-0.56 \\
(2.67) \\
\end{array}$ & $\begin{array}{c}-0.68 \\
(2.40) \\
\end{array}$ & $\begin{array}{l}-4.43 \\
(2.55) \\
\end{array}$ & $\begin{array}{l}-1.02 \\
(1.84) \\
\end{array}$ & $\begin{array}{c}-5.66 \\
(4.71) \\
\end{array}$ & $\begin{array}{l}-0.97 \\
(2.43) \\
\end{array}$ & $\begin{array}{l}-3.17 \\
(3.91) \\
\end{array}$ \\
\hline Observations & 45 & 52 & 49 & 49 & 52 & 48 & 52 & 51 & 51 & 56 \\
\hline R-squared & $\begin{array}{c}0.68 \\
\text { smair ge }\end{array}$ & $\begin{array}{c}0.74 \\
\text { ndlock m }\end{array}$ & $\begin{array}{c}0.63 \\
\text { antemp lt }\end{array}$ & $\begin{array}{c}0.63 \\
\text { 0km lene }\end{array}$ & $\begin{array}{r}0.61 \\
\text { g state }\end{array}$ & 0.65 & 0.74 & 0.60 & 0.63 & 0.55 \\
\hline Instruments & & & ardum & & & smajr & $\begin{array}{r}\text { eog ethno } \\
\text { len }\end{array}$ & $\begin{array}{l}\text { ac landloc } \\
\text { g state elv }\end{array}$ & $\begin{array}{l}\text { meantemp } \\
\text { ardum }\end{array}$ & t100km \\
\hline Heteroskedasticity test: (p-value) & 0.00 & 0.00 & 0.00 & 0.00 & 0.00 & 0.00 & 0.00 & 0.00 & 0.00 & 0.00 \\
\hline Over-identification test: (p-value) & 0.36 & 0.62 & 0.31 & 0.30 & 0.27 & 0.30 & 0.66 & 0.51 & 0.19 & 0.21 \\
\hline Endogeneity test: (p-value) & 0.30 & 0.22 & 0.30 & 0.31 & 0.12 & 0.21 & 0.18 & 0.27 & 0.48 & 0.22 \\
\hline F-Test for excluded instruments: (p-value) & 0 & 0 & 0 & 0 & 0 & 0 & 0 & 0 & 0 & 0 \\
\hline
\end{tabular}

Note: Constants are not reported. Robust standard errors adjusted for clustering by country in parentheses. Z-statistics. $* * *$ Significant at 1 percent, $* *$ Significant at 5 percent, $*$ Significant at 10 percent 
Table A15: Panel data: DQI in developing world

\begin{tabular}{|c|c|c|c|c|c|c|c|c|}
\hline & \multicolumn{8}{|c|}{ Dependent variable: Development Quality Index } \\
\hline & \multicolumn{4}{|c|}{ POOLED estimates-OLS } & \multicolumn{4}{|c|}{$\begin{array}{l}\text { Fixed effects-within group } \\
\end{array}$} \\
\hline Institutional Quality Index(IQI) & $\begin{array}{c}0.96^{* * * *} \\
(0.15)\end{array}$ & & & & $\begin{array}{c}0.35 * * * \\
(0.13)\end{array}$ & & & \\
\hline Political IQI & & $\begin{array}{c}0.78 * * * \\
(0.15)\end{array}$ & & & & $\begin{array}{c}0.35 * * * \\
(0.10)\end{array}$ & & \\
\hline Social IQI & & & $\begin{array}{c}1.09 * * * \\
(0.24)\end{array}$ & & & & $\begin{array}{c}0.54 \\
(0.17)\end{array}$ & \\
\hline Economic IQI & & & & $\begin{array}{c}1.43 * * * \\
(0.24)\end{array}$ & & & & $\begin{array}{c}0.22 * * * * \\
(0.15)\end{array}$ \\
\hline Economic policy (EPOL) & $\begin{array}{c}0.41 * * * \\
(0.13)\end{array}$ & $\begin{array}{c}0.51 * * * \\
(0.14)\end{array}$ & $\begin{array}{c}0.40 * * * \\
(0.15)\end{array}$ & $\begin{array}{c}0.34 * * * \\
(0.11)\end{array}$ & $\begin{array}{c}0.25 * * * \\
(0.08)\end{array}$ & $\begin{array}{c}0.24 * * * \\
(0.07)\end{array}$ & $\begin{array}{c}0.25 * * * \\
(0.07)\end{array}$ & $\begin{array}{c}0.30^{* * * *} \\
(0.08)\end{array}$ \\
\hline Geography(GEOG) & $\begin{array}{c}2.69 * * * \\
(0.49)\end{array}$ & $\begin{array}{c}2.94 * * * \\
(0.55)\end{array}$ & $\begin{array}{c}3.03 * * * \\
(0.51)\end{array}$ & $\begin{array}{c}2.25 * * * \\
(0.52)\end{array}$ & & & & \\
\hline \# Observations & 375 & 375 & 375 & 375 & 375 & 375 & 375 & 375 \\
\hline \# Countries & 75 & 75 & 75 & 75 & 75 & 75 & 75 & 75 \\
\hline R-squared & 0.48 & 0.43 & 0.41 & 0.46 & 0.28 & 0.22 & 0.19 & 0.17 \\
\hline F-test & 34.88 & 31.05 & 29.36 & 27.31 & 14.90 & 15.35 & 14.77 & 13.28 \\
\hline Hausman test[p-value] & & & & & 0.08 & 0.01 & 0.00 & 0.02 \\
\hline Breusch-Pagan test[p-value] & 0.00 & 0.00 & 0.00 & 0.00 & & & & \\
\hline
\end{tabular}

Note: Notes: Constants are not reported. Robust standard errors adjusted for clustering by country in parentheses. t-statistics.

$* * *$ Significant at 1 percent, $* *$ Significant at 5 percent, $*$ Significant at 10 percent 
Table A16: : Panel data: DQI in developing world

\begin{tabular}{|c|c|c|c|c|c|c|c|c|}
\hline & \multicolumn{8}{|c|}{ Dependent variable: Development Quality Index } \\
\hline & \multicolumn{4}{|c|}{ Panel corrected standard errors (PCSE) } & \multicolumn{4}{|c|}{ Generalised least squares-Panel specific AR1 (GLS) } \\
\hline Index(IQI) & $\begin{array}{c}0.57 * * * \\
(0.09)\end{array}$ & & & & $\begin{array}{c}0.18 * * * \\
(0.05)\end{array}$ & & & \\
\hline Political IQI & & $\begin{array}{c}0.38^{* * * *} \\
(0.08)\end{array}$ & & & & $\begin{array}{c}0.13^{* * * *} \\
(0.05)\end{array}$ & & \\
\hline Social IQI & & & $\begin{array}{c}0.67 * * * \\
(0.10)\end{array}$ & & & & $\begin{array}{c}0.42 * * * * \\
(0.08)\end{array}$ & \\
\hline Economic IQI & & & & $\begin{array}{c}0.48 * * * \\
(0.11)\end{array}$ & & & & $\begin{array}{c}0.05 \\
(0.06)\end{array}$ \\
\hline Economic policy (EPOL) & $\begin{array}{c}0.21^{* * *} \\
(0.05) \\
\end{array}$ & $\begin{array}{c}0.25^{* * * *} \\
(0.05) \\
\end{array}$ & $\begin{array}{c}0.25^{* * *} \\
(0.05) \\
\end{array}$ & $\begin{array}{c}0.27 * * * \\
(0.05) \\
\end{array}$ & $\begin{array}{r}0.06^{* * *} \\
(0.03) \\
\end{array}$ & $\begin{array}{c}0.09^{* * * *} \\
(0.03) \\
\end{array}$ & $\begin{array}{c}0.11^{* * * *} \\
(0.03) \\
\end{array}$ & $\begin{array}{c}0.17 * * * \\
(0.02) \\
\end{array}$ \\
\hline \# Observations & 375 & 375 & 375 & 375 & 375 & 375 & 375 & 375 \\
\hline \# Countries & 75 & 75 & 75 & 75 & 75 & 75 & 75 & 75 \\
\hline R-squared & 0.64 & 0.64 & 0.77 & 0.71 & & & & \\
\hline Wald test & 60.03 & 46.62 & 92.26 & 59.87 & 17.37 & 14.83 & 40.14 & 70.38 \\
\hline Log likelihood & & & & & 31.81 & 24.68 & -18.30 & -0.74 \\
\hline
\end{tabular}

Note: Notes: Constants are not reported. Robust standard errors adjusted for clustering by country in parentheses. Z-statistics. $* * *$ Significant at 1 percent, **Significant at 5 percent, * Significant at 10 percent 
Table A17: Panel data: DQI in developing world with Economic policy measures

\begin{tabular}{|c|c|c|c|c|c|c|c|c|c|c|}
\hline \multirow[b]{3}{*}{ Institutional Quality Index(IQI) } & \multicolumn{10}{|c|}{ Dependent variable: Development Quality Index } \\
\hline & \multicolumn{5}{|c|}{ Fixed effects-within group } & \multicolumn{5}{|c|}{ Generalised least squares-Panel specific AR1(GLS) } \\
\hline & $\begin{array}{c}0.43 * * * \\
(0.14)\end{array}$ & $\begin{array}{c}0.37 * * * * \\
(0.13)\end{array}$ & $\begin{array}{c}0.37 * * * \\
(0.15)\end{array}$ & $\begin{array}{c}0.42 * * * \\
(0.12)\end{array}$ & $\begin{array}{c}0.35^{* *} \\
(0.16)\end{array}$ & $\begin{array}{c}0.80^{* * * *} \\
(0.04)\end{array}$ & $\begin{array}{c}0.52 * * * \\
(0.05)\end{array}$ & $\begin{array}{c}0.50 * * * \\
(0.05)\end{array}$ & $\begin{array}{c}0.59 * * * \\
(0.05)\end{array}$ & $\begin{array}{c}0.76 * * * \\
(0.05)\end{array}$ \\
\hline Economic policy (EPOL) & & & & & $\begin{array}{l}0.31 * * \\
(0.14)\end{array}$ & & & & & $\begin{array}{c}0.28 * * * \\
(0.04)\end{array}$ \\
\hline Inflation & $\begin{array}{c}-0.12 * * * * \\
(0.02)\end{array}$ & & & & $\begin{array}{c}-0.10 * * * \\
(0.02)\end{array}$ & $\begin{array}{c}-0.18 * * * \\
(0.01)\end{array}$ & & & & $\begin{array}{c}-0.10^{* * * *} \\
(0.01)\end{array}$ \\
\hline Exchange rate differential (Official vs. BMP) & & $\begin{array}{c}0.02 * * * \\
(0.00)\end{array}$ & & & $\begin{array}{l}-0.00 \\
(0.00)\end{array}$ & & $\begin{array}{c}0.01 \\
(0.00)\end{array}$ & & & $\begin{array}{c}-0.02 * * * * \\
(0.00)\end{array}$ \\
\hline Credit market de-regulation & & & $\begin{array}{c}0.04 * * * \\
(0.01)\end{array}$ & & $\begin{array}{l}-0.00 \\
(0.02)\end{array}$ & & & $\begin{array}{c}0.01 \text { *** } \\
(0.0)\end{array}$ & & $\begin{array}{l}-0.00 \\
(0.00)\end{array}$ \\
\hline Capital liberalization measures & & & & $\begin{array}{l}0.20^{*} \\
(0.10) \\
\end{array}$ & $\begin{array}{c}0.19 * * \\
(0.09) \\
\end{array}$ & & & & $\begin{array}{c}0.19^{* * * *} \\
(0.04) \\
\end{array}$ & $\begin{array}{c}0.28 * * * * \\
(0.03) \\
\end{array}$ \\
\hline \# Observations & 316 & 333 & 329 & 375 & 294 & 316 & 333 & 329 & 375 & 294 \\
\hline \# Countries & 72 & 67 & 67 & 75 & 67 & 72 & 67 & 67 & 75 & 67 \\
\hline R-squared & 0.25 & 0.20 & 0.20 & 0.29 & 0.28 & & & & & \\
\hline F-test & 21.74 & 12.02 & 8.77 & 10.17 & 8.16 & & & & & \\
\hline Wald Statistics & & & & & & 3808.53 & 96.22 & 98.79 & 177.82 & 400.44 \\
\hline Log likelihood & & & & & & 13.07 & -1.17 & 7.89 & 13.52 & -2.81 \\
\hline Hausman test[p-value] & 0.12 & 0.05 & 0.00 & 0.00 & 0.00 & & & & & \\
\hline Breusch-Pagan test[p-value] & 0 & 0 & 0 & 0 & 0 & & & & & \\
\hline
\end{tabular}

Note: Notes: Constants are not reported. Robust standard errors adjusted for clustering by country in parentheses. t-statistics for fixed effects, and Zstatistics for GLS .***Significant at 1 percent, $* *$ Significant at 5 percent, $*$ Significant at 10 percent 
Table A18: SYSTEM GMM: Blundell and Bond (1998), two-step procedure, determinants of DQI

\begin{tabular}{|c|c|c|c|c|c|c|c|c|}
\hline \multirow[b]{3}{*}{ Lag of DQI } & \multicolumn{8}{|c|}{ Dependent variable: Development Quality Index } \\
\hline & \multicolumn{4}{|c|}{ Whole sample } & \multicolumn{4}{|c|}{ Developing country sample } \\
\hline & $\begin{array}{c}0.71 * * * \\
(0.08)\end{array}$ & $\begin{array}{c}0.90 * * * \\
(0.05)\end{array}$ & $\begin{array}{c}0.86 * * * \\
(0.06)\end{array}$ & $\begin{array}{c}0.74^{* * * *} \\
(0.06)\end{array}$ & $\begin{array}{c}0.86^{* * * *} \\
(0.05)\end{array}$ & $\begin{array}{c}0.93 * * * \\
(0.04)\end{array}$ & $\begin{array}{c}0.91 * * * \\
(0.05)\end{array}$ & $\begin{array}{c}0.90 * * * \\
(0.05)\end{array}$ \\
\hline Institutional Quality Index(IQI) & $\begin{array}{c}1.66 * * * * \\
(0.32\end{array}$ & & & & $\begin{array}{c}0.47^{* * * *} \\
(0.14)\end{array}$ & & & \\
\hline Political IQI & & $\begin{array}{l}0.81 * * \\
(0.34)\end{array}$ & & & & $\begin{array}{c}0.23 * * \\
(0.11)\end{array}$ & & \\
\hline Social IQI & & & $\begin{array}{c}1.08^{* * * *} \\
(0.44)\end{array}$ & & & & $\begin{array}{c}0.52 * * * \\
(0.19)\end{array}$ & \\
\hline Economic IQI & & & & $\begin{array}{c}2.21 * * * \\
(0.47)\end{array}$ & & & & $\begin{array}{c}0.46^{* *} \\
(0.20)\end{array}$ \\
\hline Economic policy (EPOL) & $\begin{array}{l}0.61 * * \\
(0.30)\end{array}$ & $\begin{array}{l}0.74 * * \\
(0.31)\end{array}$ & $\begin{array}{c}0.39 \\
(0.28)\end{array}$ & $\begin{array}{l}0.32 \\
(0.27)\end{array}$ & $\begin{array}{c}0.01 \\
(0.03)\end{array}$ & $\begin{array}{l}-0.02 \\
(0.10)\end{array}$ & $\begin{array}{l}-0.06 \\
(0.10)\end{array}$ & $\begin{array}{l}-0.04 \\
(0.08)\end{array}$ \\
\hline Inflation & $\begin{array}{c}0.05 \\
(0.08)\end{array}$ & $\begin{array}{c}0.07 \\
(0.08)\end{array}$ & $\begin{array}{c}0.07 \\
(0.08)\end{array}$ & $\begin{array}{c}0.16^{* * * *} \\
(0.07)\end{array}$ & $\begin{array}{l}-0.08 \\
(0.09)\end{array}$ & $\begin{array}{l}-0.06^{*} \\
(0.03)\end{array}$ & $\begin{array}{c}-0.08^{* *} \\
(0.04)\end{array}$ & $\begin{array}{l}-0.04 \\
(0.03)\end{array}$ \\
\hline Exchange rate differential (Official vs. BMP) & $\begin{array}{c}0.00 \\
(0.02)\end{array}$ & $\begin{array}{c}0.02 \\
(0.02)\end{array}$ & $\begin{array}{c}0.05 \\
(0.02)\end{array}$ & $\begin{array}{c}0.00 \\
(0.03)\end{array}$ & $\begin{array}{l}-0.00 \\
(0.02)\end{array}$ & $\begin{array}{c}0.00 \\
(0.01)\end{array}$ & $\begin{array}{c}0.00 \\
(0.01)\end{array}$ & $\begin{array}{l}-0.00 \\
(0.01)\end{array}$ \\
\hline Credit market de-regulation & $\begin{array}{c}0.04 \\
(0.05)\end{array}$ & $\begin{array}{c}0.06 \\
(0.05)\end{array}$ & $\begin{array}{c}0.01 \\
(0.05)\end{array}$ & $\begin{array}{l}0.09 * \\
(0.05)\end{array}$ & $\begin{array}{l}0.04^{*} \\
(0.02)\end{array}$ & $\begin{array}{l}-0.03 \\
(0.03)\end{array}$ & $\begin{array}{c}-0.04 * * \\
(0.02)\end{array}$ & $\begin{array}{l}-0.02 \\
(0.02)\end{array}$ \\
\hline Capital liberalization measures & $\begin{array}{c}0.16 \\
(0.24)\end{array}$ & $\begin{array}{c}0.12 \\
(0.18)\end{array}$ & $\begin{array}{c}0.08 \\
(0.22)\end{array}$ & $\begin{array}{c}0.05 \\
(0.21)\end{array}$ & $\begin{array}{c}0.10 \\
(0.11)\end{array}$ & $\begin{array}{c}0.10 \\
(0.12)\end{array}$ & $\begin{array}{c}0.10 \\
(0.11)\end{array}$ & $\begin{array}{c}0.02 \\
(0.10)\end{array}$ \\
\hline \# Observations & 340 & 340 & 340 & 340 & 241 & 241 & 241 & 241 \\
\hline \# Countries & 92 & 92 & 92 & 92 & 67 & 67 & 67 & 67 \\
\hline $\mathrm{m} 1=$ first order autocorrelation & 0.01 & 0.00 & 0.02 & 0.00 & 0.00 & 0.00 & 0.00 & 0.00 \\
\hline $\mathrm{m} 2=$ Second order autocorrelation & 0.35 & 0.42 & 0.06 & 0.74 & 0.42 & 0.20 & 0.20 & 0.27 \\
\hline Hansen J test [p-value] & 0.17 & 0.23 & 0.10 & 0.24 & 0.30 & 0.28 & 0.25 & 0.16 \\
\hline
\end{tabular}

Note: Constants are not reported. Year dummies are included in all model specifications. t-statistics ***Significant at 1 percent, $* *$ Significant at 5 percent, * Significant at 10 percent. The SYS-GMM results are two step estimates with heteroskedasticity consistent standard errors are based on the finite sample adjustment of Windmeijer (2005). $\mathrm{m} 1$ and $\mathrm{m} 2$ tests are p-values of the null of no first-order and no-second order auto-correlation.

Hansen $\mathrm{J}$ tests are p-values of the over-identifying restrictions for GMM estimators, appropriate set of instruments. 


\section{References}

Acemoglu, D., S. Johnson, and J. A. Robinson (2001). "The Colonial Origins of Comparative Development: An Empirical Investigation," American Economic Review 91.

Acemoglu, D., S. Johnson and J. A. Robinson (2002). "Reversal of Fortune: Geography and Institutions in Making of the Modern World Income Distribution," Quarterly Journal of Economics 117.

Acemoglu, D., S. Johnson and J. A. Robinson (2004). "Institutions as the Fundamental Cause of Long-Run Growth," NBER Working Paper No. 10481.

Adelman, I., and C.T. Morris (1967). Society, Politics and Economic Development. Johns Hopkins University Press, Baltimore.

Alesina, A., A. Devleeschauwer, W. Easterly, S. Kurlat and R. Wacziarg (2003). "Fractionalization," Journal of Economic Growth 8.

Arellano, M and S. Bond (1991). "Some tests of specification for panel data: monte-carlo evidence and an application to employment equations," Review of Economic Studies 58

Anand, S. and A.Sen (1994). "Human development Index: Methodology and Measurement," Occasional Paper No.12, Human Development Report Office. United Nations.

Baldwin, R., P. Martin and G.I. P. Ottavano (2001). "Global Income Divergence, Trade, and Industrialization: The Geography of Growth Take-Offs," Journal of Economic Growth 6.

Baltagi, B. H. (1995). Econometric Analysis of Panel Data, Wiley, Chichester.

Bardhan, P. (2005). "Institutions matter, but which ones?" Economics of Transition 13.

Barro, R. (2001). "Quantity and Quality of Economic Growth," Fifth Annual Conference of the Central Bank of Chile.

Barro, R. and J-W. Lee (2000). "International Data on Educational Attainment: Updates and Implications," CID Working Paper \#42, Harvard University.

Basu, S. R (2002). "Does Governance Matter? Some Evidence from Indian States," Paper presented at the VIIth Spring Meeting of Young Economists, 17-19 April, Paris, France.

Basu, S. R (2003a). "Estimating the quality of economic governance: A cross-country analysis," Paper presented at the Swiss Society of Economics and Statistics Annual Congress, March 20-21, Bern, Switzerland.

Basu, S. R (2003b). "Measuring Economic Well-Being and Governance: Some Methodological Tools," in Simos, T.E. (ed.) Proceedings of the International Conference of Computational Methods in Sciences and Engineering 2003 (ICCMSE 2003), World Scientific, New Jersey.

Basu, S.R., L.R. Klein and A.L. Nagar (2005). "Quality of Life: Comparing India and China," The paper presented at Project LINK meeting, 1 November, UN Office, Geneva.

Basu, S.R (2006). "Economic growth, well-being and governance under economic reforms: Evidence from Indian States" Journal of World Economics Review.

Basu, S.R., S. Fan and X. Zhang (2006). "Welfare Comparison beyond GDP," The paper presented at the International Conference on the Dragon and the Elephant: China and India's Economic Reforms, June 30- July 2, 2006, China Executive Leadership Academy Pudong, Shanghai, China

Basu, S.R. (2007). "Institutions, policies and foreign direct investment: A fresh look", Paper presented at XIIth Spring Meeting of Young Economists, Hamburg, Germany.

Basu, S.R. (2008). "A new way to link development to institutions, policies and geography", Policy issues in international trade and commodities, UNCTAD/ITCD/TAB/38, United Nations, New York and Geneva. 
Basu, S.R. and M. Das (2008). "Institution and Development Revisited: A Nonparametric Approach". HEI Working Paper Number: 05-2008, International Economics Department, Graduate Institute of International Studies, Geneva. March 2008.

Baum, C., M.E. Schaffer, and S. Stillman (2003). "Instrumental variables and GMM: Estimation and Testing," Working Paper No. 545, Boston College.

Bloom, D.E., and J.D. Sachs (1998). "Geography, Demography, and Economic Growth in Africa," Brookings Papers on Economic Activity: 2, Brookings Institution.

Blundell, R. and S. Bond (1998). "Initial Conditions and Moment Restrictions in Dynamic Panel Data Models," Journal of Econometrics 87.

Bond, S. (2002). "Dynamic Panel Data Models: A Guide to Micro Data Methods and Practice", Cemmap Working Paper 09/02, Institute for Fiscal Studies.

Chong, A. (2000). "On the Causality and Feedback Between Institutional Measures and Economic Growth," Economics and Politics, 12(1) 69-81.

Cingranelli-Richards (CIRI). "Human Rights Dataset". http://ciri.binghamton.edu/

Dasgupta, P. and M.Weale. (1992). "On Measuring the Quality of Life," World Development, 20,1, 119-131.

Dixit, A (2005). "Evaluating recipes for development success," Economics Department, Princeton University.

Dollar, D. and A. Kraay (2001). "Trade, Growth, and Poverty," World Bank, Policy Research Working Paper No. 2199.

Dollar, D. and A. Kraay (2003). "Institutions, Trade, and Growth: Revisiting the Evidence," Policy Research Working Paper Series 3004, The World Bank

Diamond, J. (1997). Guns, Germs, and Steel, New York: W.W. Norton \& Co.

Edwards, S. (1998). 'Openness, Productivity and Growth: What do we really know?' Economic Journal, 108, 383-398

Easterly, W. and R. Levine (2003). “Tropics, Germs, and Crops: How Endowments Influence Economic Development," Journal of Monetary Economic 50.

Easterly, W. (2004). "National Economic Policies and Economic Growth: A Reappraisal," in Handbook of Economic Growth, Aghion, P and S. Durlauf (eds.), North-Holland, Elsevier, Amsterdam.

Frankel, J.A. and D. Romer, (1999). "Does Trade Cause Growth?," American Economic Review 89.

Heritage Foundation (2006), Index of Economic Freedom. http://www.heritage.org/research/features/index/

Gallup, J.L., J.D. Sachs and A.D. Mellinger (1998). "Geography and Economic Development," Harvard Institute of Economic Research Working Papers 1856, Harvard - Institute of Economic Research.

Gallup, J.L., and J.D. Sachs (2001). "The Economic Burden of Malaria," The Supplement to The American Journal of Tropical Medicine \& Hygiene 64.

Giavazzi, F. and G. Tabellini (2004). "Economic and Politcial Liberalizations." IGIER Working Paper No. 264, Milan.

Glaeser, E., R. La Porta, F. Lopez-de-Silanes and A. Shleifer (2004). "Do Institutions cause growth?" Journal of Economic Growth 9.

Hadi, A. S. (1992). "A New Measure of Overall Potential Influence in Linear Regression," Computational Statistics and Data Analysis 14.

Hall, R. and C.I. Jones (1999). "Why Do Some Countries Produce So Much More Output per Worker than Others?" Quarterly Journal of Economics 114.

Hausman, J. (1978). "Specification tests in econometrics," Econometrica 46.

Hibbs, D.A. and O. Olsson (2004). "Geography, biogeography, and why some countries are rich and others are poor", PNAS, 101. 
Hibbs, D. A., and O. Olsson (2005). "Biogeography and long-run economic development" European Economic Review 49.

Kaufmann, D., A. Kraay and M. Mastruzzi, (2005). "Governance Matters IV: Governance Indicators for 1996-2004, The World Bank.

Kaufmann., D. and A. Kraay (2003). "Governance and Growth: Causality Which Way?," The World Bank.

Klein L.R., and S. Ozmucur (2002/2003). "The Estimation of China's Economic Growth," Journal of Economic and Social Measurement 62.

Knack, S. (1997). "Why Don't Poor Countries Catch Up? A Cross-Country Test of an Institutional Explanation," Economic Inquiry 35.

Masters, W.A. and M.S.McMillan (2001). "Climate and Scale in Economic Growth," Journal of Economic Growth 6.

McArthur, J.W. and J. Sachs (2001). "Institutions and Geography: Comment on Acemoglu, Johnson and Robinson," NBER Working Paper 8114.

Montesquieu, C. de S (1748). The Spirit of the Laws. Paris.

Morris, D. Morris. (1979). Measuring the Condition of the Words' Poor: The Physical Quality of Life Index. New York, Pergamon.

Muqtada, M (2003). "Macroeconomic Stability, Growth and Employment: Issues and Considerations Beyond the Washington Consensus," EMP Working Paper \# 48, International Labour Organization, Geneva.

Mussa, Michael (2000). "Factors Driving Global Economic Integration," paper presented in Jackson Hole, Wyoming at a symposium sponsored by the Federal Reserve Bank of Kansas City on "Global Opportunities and Challenges," August 25.

Nagar, A.L. (1959). "The Bias and Moment Matrix of the General k-Class Estimators of the Parameters in Simultaneous Equations," Econometrica 27.

Nagar, A.L. and Y.P. Gupta (1970). "The Moment Matrix of the Two-Stage Least-Squares Estimators of Coefficients in Different Equations of a Complete System of Simultaneous Equations," Econometrica 38.

Nagar, A.L. and S. R. Basu. (2002). "Weighting Socio-Economic Indicators of Human Development: A Latent Variable Approach," in Ullah, A. et al (eds.) Handbook of Applied Econometrics and Statistical Inference, Marcel Dekker, New York, USA.

Nagar, A.L. and S. R. Basu. (2004). "Statistical Properties of a Composite Index as Estimate of a Single Latent Variable," Journal of Quantitative Economics, Special Issue; 2(2).

North, D. C. (1990). Institutions, Institutional Change and Economic Performance. Cambridge: Cambridge University Press.

North, D. C. (1992). “The New Institutional Economic and Development" Washington Univesity, St. Louis.

North, D. C. (1994). "Institutions Matter," Economic History, Economics Working Paper Archive at WUSTL.

Polity IV Project (2003). "Political Regime Characteristics and Transitions, 1800-2003," by M.G. Marshall, K. Jaggers, and T.R. Gurr. http://www.cidem.umd.edu/inscr/polity/

PRIO (International Peace Research Institute). "Vanhanen's index of democracy," http://www.prio.no/cwp/vanhanen/

PRS Group (2006). International Country Risk Guide (ICRG) http://www.prsgroup.com/

Przerworski, A. (2004). "Geography vs Institutions Revisited: Were Fortunes Reversed?" Mimeo, New York University.

Rodríguez F. and D.Rodrik (2000). "Trade Policy and Economic Growth: A Skeptic's Guide to the Cross-National Evidence", NBER Macroeconomics Annual. 
Rodríguez, F. (2006). “Openness and Growth: What Have We Learned?" The paper was prepared as a background note for the United Nations' 2006 World Economic and Social Survey.

Rodrik, D., A. Subramanian and F. Trebbi, (2004). "Institutions Rule: The Primacy of Institutions over Geography and Integration in Economic Development," Journal of Economic Growth, 9.

Sachs, J.D. and A.Warner (1995). "Economic reform and the Process of Global Integration,"Brookings paper on Economic Activity, 1, 1-118.

Sachs, J.D. (2003a). "Institutions Don't Rule: Direct Effects of Geography on Per Capita Income," NBER Working Papers 9490, National Bureau of Economic Research.

Sachs, J.D. (2003b). "Institutions matter, but not for everything," Finance and Development, June, International Monetary Fund, Washington, D.C.

Sen, A.K. (1999). Development as Freedom. Oxford University Press

Sengupta, A (2000). "The Right to Development as a Human Right," François-Xavier Bagnoud Center for Health and Human Rights, Harvard University.

Staiger, D. and J. H. Stock (1997). "Instrumental Variables Regression with Weak Instruments," Econometrica 65.

Stiglitz, J. (1999). "Whither Reform? Ten Years of the Transition," ABCDE, World Bank, Washington, D.C. April 28-30.

Shea, J. (1997). "Instrument relevance in multivariate linear models: A simple measure," Review of Economics and Statistics 79.

Swamy, A., S.Knack, Y. Lee and O. Azfar (1999). "Gender and Corruption,” Draft Paper, IRIS Center, University of Maryland.

United Nations (1954). International Definition and Measurement of Standards and Levels of Living. New York, United Nations.

United Nations (2005). African Governance Report, Economic Commission for Africa, Addis Ababa, Ethiopia

United Nations (2006). Diverging Growth and Development, World Economic and Social Survey, DESA, New York, United Nations.

United Nations (2007). Developing Countries in International Trade 2007: Trade and Development Index. UNCTAD, New York and Geneva, United Nations.

United Nations (1990- present). Human Development Report. UNDP, New York, Oxford University Press.

Wacziarg, R and K.H. Welch (2003). "Trade Liberalization and Growth: New Evidence". NBER Working Paper No. 10152.

Williamson, J. (2002). "Did the Washington Consensus Fail?" Institute for International Economics.

Windmeijer, F. (2005). "A Finite Sample Correction for the Variance of Linear Efficient TwoStep GMM Estimators," Journal of Econometrics 126.

Witold H. (2006). "Political Constraint Index (POLCON) Dataset", University of Pennsylvania. http://www-management.wharton.upenn.edu/henisz/

Wooldrigde, J. (2002). Econometric Analysis of Cross Section and Panel Data. Cambridge. MA, MIT Press.

World Bank (2000). The Quality of Growth. Oxford University Press, New York.

World Bank (2003). Sustainable Development in a Dynamic World: Transforming Institutions, Growth, and Quality of Life. World Development Report. Oxford University Press, New York.

World Bank (2006). The World Development Indicator, CD-ROM 2006. 